\title{
Improving scenario methods in infrastructure planning: A case study of Long Distance Travel and Mobility in the UK under Extreme Weather Uncertainty and a Changing Climate
}

\author{
Alberto M Zanni ${ }^{\mathrm{a}^{*}}$, Murray Goulden ${ }^{\mathrm{b}}$, Tim Ryley ${ }^{\mathrm{d}}$, Robert Dingwall ${ }^{\mathrm{b}, \mathrm{c}}$ \\ Transport Studies Group - School of Civil and Building Engineering - Loughborough University-UK ${ }^{a}$ \\ Horizon Digital Economy Research Institute, University of Nottingham-UK ${ }^{b}$ \\ Dingwall Enterprises Ltd, Nottingham - UK \\ ${ }^{d}$ Griffith Aviation, School of Natural Sciences, Griffith University, Australia
}

\begin{abstract}
This paper develops a mixed method approach to infrastructure planning through a United Kingdom (UK) case study examining the impact of a changing climate on long distance travel and mobility between London and Glasgow. A novel combination of a qualitative method - Systematic Qualitative Foresight (SQF) - and quantitative simulation using discrete choice stated preference methods is applied. The main dataset is a travel behaviour survey of over 2,000 residents of London and Glasgow. Three illustrative SQF-based scenarios are developed incorporating society, technology and climate dimensions. For each scenario, the choice of long-distance travel mode by two groups of respondents generated by cluster analysis is simulated using stated preference survey data to describe the choices likely to be made by actors within each scenario.

We demonstrate the importance of considering a wide range of variables when creating instruments for infrastructure planning decisions. Our results show that weather-related disruption has consequences for travel behaviour, with a considerable number of travellers deciding not to travel despite the importance of their trip. However, the vast majority of travellers would still travel. This should be considered by policy makers, and those responsible for transport infrastructure, in order to increase its resilience to extreme weather and demand, and better devise contingencies plans to contain, and minimise, the effect of the disruptions on the users. The method described has wider implications for infrastructure planning, particularly in its ability to engage a broader range of stakeholders and to avoid linear models of prediction. By emphasising the creation of a plausible decision space, it offers the possibility of increased robustness and resilience in infrastructure planning.
\end{abstract}

\section{Keywords}

Resilience, climate, transport, technology, discrete choice, scenarios

\footnotetext{
* corresponding author:

The research work on which this paper is based was carried out when the first author was a Research Associate at Loughborough University. Email: amz@albertomzanni.com
} 


\section{Introduction}

A key problem in making planning decisions about major infrastructure projects is the potential length of the investment cycle. Transport systems are a particularly good example. At the extreme, the route decisions of Roman military engineers dictated the broad outline of the English road network until the construction of motorways in the 1960s. United Kingdom (UK) railways are still constrained by the technological limits of Victorian civil engineering in boring some of the tunnels that modern rolling stock must pass through. This is a specific case of a general problem familiar to social scientists, namely how societies manage to make investments in the present that will have to function in an unknown, and unknowable, future. If these decisions are wrong, then resources that could have been put to better use have been wasted. However, if the investments are not made, then their potential benefits are also foregone. All documented human societies have developed institutions and technologies to attempt to limit these risks by reducing uncertainty about, or stabilizing, the future. In traditional societies, stabilization may be achieved by consulting institutions like oracles or prophets, or by technologies like prayer and sacrifice. Modern societies have created institutions like insurance markets, based on the mathematics of probability, and technologies like econometric or demographic modelling, based on the identification and enrolment of various metrics into an algorithm. These have, however, been criticized for their reliance on data about the past as a guide to the future and for their tendency to foreclose choices about the future by a focus on technical expertise rather than public engagement. The future is produced by impersonal metrics rather than democratic consent. At the same time, many of the alternatives, in the form of scenario-based activities, seem to be based on little more than the values and preconceptions of their authors.

This paper reports on a different alternative approach, based on our work for FUTURENET, an interdisciplinary project linking engineers, geologists and social scientists to investigate the future resilience of the UK transport network in the face of climate change. The route corridor from London to Glasgow was chosen by the project team as a case study because of its importance for the UK economy, and its diversity of climatic and geographic conditions. The social science component considered long distance travel demand under potential climatic, social, economic and technological conditions, in order to characterize the needs that present-day infrastructure investments should expect to meet in the year 2050.

Transportation research has generated numerous quantitative prediction and forecasting studies of travel behaviour and vehicle choice typical of the approaches mentioned above [see for example 1, 2, 3]. A number of studies have also used scenario analysis, backcasting, Delphi and other methods from the future studies literature that variously adopt either exclusively qualitative or mixed qualitative/quantitative approaches [4-9]. The future studies literature has examined the possible evolution of urban transport systems and mobility practices [10-13], and, in particular, of the role of technology [14], and fuel and energy sources [15-17]. We have, however, been unable to identify specific studies of long distance travel, although some have discussed more general tourism patterns [see for example 18, 19]. While some studies have looked at the broad issue of extreme climate events [20], the specific effects of extreme weather events on travel behaviour have not been examined. Very recently, a number of experts in transport have again stressed the limits of traditional 
quantitative forecasting models at taking into account the variety of determinants of travel demand, as well as those of more qualitative approaches seeking mere consensus among often considerably different opinions in a particularly uncertain world [9]. Our work for FUTURENET responds to these critiques with the development of an innovative methodology that transcends conventional qualitative/quantitative distinctions by establishing a protocol for integrating diverse types of information at the point of decision. This methodology is capable of extension to the assessment of other types of major infrastructure investments.

This paper demonstrates the combination of a qualitative method called Systematic Qualitative Foresight (SQF) [21] with quantitative simulation using discrete choice stated preference methods on a large dataset in order to simulate the choice of method of travel over a number of multi-dimensional scenarios. Potential investment decisions can then be tested for resilience under different possible demand conditions rather than being constrained to generate a single vision of the future. The next section describes the methodology and methods employed in more detail. Section 3 presents the case study and some illustrative results from the simulation. Section 4 reviews the lessons from this study and considers how it might have more general application to planning large-scale, long-term infrastructure investments.

\section{Background and methodological approach}

In seeking to improve the planning tools available to those responsible for decisions about long-term investments in infrastructure, we specified a number of criteria that an approach should meet.

1. It should ensure that decision-makers consider a full range of socio-technical possibilities, particularly the interactions between their sectoral decisions and developments in other sectors of society.

2. It should be capable of accommodating as much available data as practicable, whether quantitative or qualitative.

3. It should be transparent with respect to the values taken into account by decisionmakers.

4. It should be consistent with well-established social scientific evidence on human social organization.

5. Where required, it should be capable of supporting public engagement and dialogue to test expert thinking against lay reasoning, and aid the legitimacy ascribed to its conclusions.

Our approach integrates qualitative scenarios with econometric simulation based on primary data collected through an extensive population survey. Quantitative forecast and prediction modelling generally rest on the assumption that variables and relationships that have been measured and linked in the present, or in the recent past, can be used to predict the future. This has been described as 'up-and-to-the-right' thinking, where lines on a graph are simply continued in the direction that has been established [22]. There are two particular problems with this. First, it cannot be assumed that any trend will continue indefinitely: late $19^{\text {th }}$ century city governments feared a crisis from the increasing volume of horse manure being deposited on their streets but this was prevented by the introduction of automobiles [23]. Second, the social sciences cannot sensibly impose metrics on some dimensions of social and economic life: a purely quantitative approach will inevitably exclude important data that do 
not lend themselves to numerical representation [24]. In this respect, our approach contrasts with the XLRM framework developed at RAND, which attempts to reduce all inputs to numerical forms, while accepting the need to generate a decision space rather than a linear vision of the future $[25,26]$. Recognition of these limitations has led to the parallel development of qualitative approaches.

The earliest of these, represented by the 'genius forecasting' developed by Herman Kahn and the RAND Institute during the 1950s [e.g. 27], sought to produce systematic and supposedly objective scenarios, based on explicit methodological protocols, to displace the subjective visions exemplified by the work of novelists like Jules Verne or HG Wells. The Delphi method [28] sought to progress this approach through the consolidated wisdom of key stakeholders, who are each asked to make their best individual predictions. The predictions are combined and weighted to give a pooled estimate of likely futures. The pooling process may include a number of iterations with the participants, seeking to build a consensus around the estimate. These methods can be invaluable in provoking questions and debate. However, they also have limitations as means of stabilizing the future. Expert forecasting depends heavily on the choice of experts who are consulted, which tends to incorporate unexamined normative assumptions about what counts as expertise. Moreover, the emphasis tends to be on seeking consensus rather than on finding options capable of accommodating diversity. In some technology design circles, these limitations have led to a revival of interest in the use of science fiction to propose 'what-if' questions to designers and policy-makers [22, 29]. This method attempts to envision alternative societies where a particular technology or social theory has, or has not, come into use. The use of creative or imaginative perspectives is particularly helpful in stimulating innovative thinking. However, these narratives also tend to impose closure on the possibilities of the future and to introduce unacknowledged values. For some audiences, their reliance on creative fictions may also lack the legitimacy of more formal or quantitative approaches, as noted by Groves and Lempert [25].

Systemic Qualitative Foresight (SQF) was developed as a means for identifying and exploring a design space within which possible investment decisions are likely to lie. This meets the first criterion mentioned earlier by emphasising the exploration of an array of alternatives rather than the immediate identification of a single pathway. The space is defined by a number of dimensions, each of which collates and organizes available evidence on facts and values, satisfying the second, third and fourth criteria. It generates a range of scenarios that facilitate public engagement with decision-making, satisfying the fifth criterion.

The SQF protocol begins with an exploratory brainstorming stage, where a proposed problem is analysed and the widest range of documentation is assembled. In some contexts, this would include both direct citizen and stakeholder engagement. Within the terms of the FUTURENET brief, we organised several expert workshops to discuss social, economic and cultural factors that might be relevant influences on UK travel demand through to 2050. This led us to focus on mobilities, the assumptions embedded in the social, economic and cultural organization of contemporary societies about the ability of citizens, goods and services to move around, both physically and/or virtually [30]. When journeys are disrupted, the impact is not from the event per se but from what the journey means to those who are travelling. This is often overlooked in other approaches, for example public services choice.

The brainstorming phase was also an opportunity to consider possible mobility technologies. To what extent are virtual interactions likely to displace physical interactions by 2050? Assuming that physical mobility will continue to be important, what sources of energy will be used to power travel from A to B? Are the means of travel likely to be incremental improvements on those already in existence or are disruptive possibilities already apparent? 
How quickly could disruption occur, given the length of the replacement cycle in transport infrastructure? Finally, we have been able to incorporate the climate and weather projections generated within the FUTURENET project to consider the potential risks of disruption to the chosen route corridor in 2050.

This scoping process establishes the three main axes of the design space for considering the future: Society (social, economic, cultural); Technology (fixed and moving); and Climate (weather events). Each of these can then be expanded through a discussion of the elements covered by our research. Approaching the problem in this way ensures that all three dimensions are simultaneously addressed in the process of decision-making.

The next step is to fill out the content of each considered dimension. While it is obviously impossible to list every possible variable, the most important ones can be identified and others added by decision-makers. From this, scenarios can be compiled to illustrate particular points within the space. What is distinctive about the SQF approach, however, is that the variables incorporated in the scenarios are specified in advance and are thus fully transparent to the users. This approach minimizes the opportunities for skewing scenarios to promote particular outcomes, particularly by embedding the authors' values in unexamined ways. Scenarios may be generated to focus on the middle of the space or to explore the outer limits: each is likely to have value for different purposes. This approach also moves away from the assumption that travel decisions are matters of rational individual choice, to study them as moments in the life of the social networks within which travellers are embedded. The possible futures for transport will reflect the overall level of demand - driven by national and global population and economic growth, cultural assumptions about mobility, the availability and attractiveness of competing modes, the resources available for investment generated by national economic performance, etc.

\subsection{Building the scenarios}

For the purposes of this case study, all scenarios will be set in the month of April 2050. This month has been selected because it normally presents a range of weather events but is generally not characterized by extremes of heat or cold. The weather conditions will also be influenced by the overall climate pathway, which will be discussed later. We shall now discuss each of the axes that define the space for generating scenarios.

\section{Society Axis}

The Society axis of the design space is the most complex and can present a number of contexts. These may be relatively mundane or they may deliberately exaggerate some possibilities in order to provoke discussion about the compromises that may need to be made in any real future. Scenarios are not forecasts or predictions: their value lies in confronting people with visions of possible futures, inviting them to consider the advantages and disadvantages and to explore ways in which desirable goals can be maximized and undesirable ones minimized. In this manner the future is recognised as being actively constructed in the present, rather than as a pre-determined state to be discovered.

\section{Demography}

Transport demand will be affected by the size and structure of the UK population. The 2011 census estimates from the Office for National Statistics [31] suggest that the UK population is currently 63.2 million, with about 16 per cent over the age of 65. By 2035, it is likely to lie somewhere within a range from to 68 to 78 million, with the proportion over 65 between 21 and 25 per cent. Figures are more uncertain for 2050 but current ONS estimates suggest a 
range between 69 and 88 million, with the proportion over 65 within a range from 21 to 28 per cent. On a low economic growth pathway, population is likely to grow more slowly. On a high growth pathway, the converse is likely to be true. Current projections also suggest that the number of households is likely to grow by 29 per cent between 2006 and 2031, with twothirds of the increase accounted for by single-person households, particularly among older people. Comparable projections are not available for 2050 but whatever happens beyond 2030 is likely to start from a higher base than today [32]. An increase in the number of households implies an increase in transport requirements because everyday mobility demand does not decline proportionately to household size. Indeed, this may even increase if people are required to travel more in order to replace the social and psychological supports of living with others. We can also infer that there is likely to be increased transport demand from carers, whether kin or paid, or to access public care services.

If climate change accelerates, however, the UK may become a more favoured destination for migrants, for example from an increasing hot Africa. By 2050, this could be a growing pressure on the European Union (EU) as a whole, rather than the UK in particular, but some climate projections suggest that parts of Southern Europe may not be sustainable places to live by the second half of the century. If so, we may see migration pressure from these zones on more northerly parts of the EU. The same could well apply to tourism. Within a range of plausible scenarios, we could imagine a flat UK economy with substantial population growth from climate refugees, depending upon EU and UK immigration policy. Migration obviously affects international transport demand. If migration flows are primarily within Europe, there could be some substitution of surface transport for air travel . Internal migration may be more important, as unevenly distributed economic opportunities seem likely to remain characteristic of the UK.

\section{Economy}

Economic activity is one of the major drivers for transport demand. Other things being equal, an active economy will generate more mobility (both freight and people) than will a stagnant one. The present context is one of great uncertainty about the likely course of economic activity, and the level of funding for transport infrastructure during the next five to ten years, which will, in turn, frame the longer-term possibilities. Scenarios need to reflect this.

\section{Culture and Values}

One of the hardest areas to incorporate in scenario design is any presumed shift in societal values over a relatively short period. Some scenarios might be based on a 'Deep-Green' Utopia of a planet with 2 billion or fewer inhabitants. Advocates of these outcomes tend to depict a world dominated by communitarian values, which favour village-scale communities, depending largely on their own local resources, with very limited travel and trading between them [33]. Scenarios should, then, also recognize and give equal weight to an alternative utopia where markets are allowed free play to allocate resources. In theory, their advocates argue, properly functioning markets will send signals to consumers through the price mechanism that will influence their mobility decisions in a fashion that is sensitive to externalities like climate change [34].

\section{Other Societal Dimensions}

Household size and distribution will, for example, be strongly affected not just by demography but also by economic growth and the ability of the population to fund solo living, and by the preferences for privacy versus community. UK land use planning has generally produced higher residential densities, and less suburban sprawl, than in North America or Australia, facilitating the sustainable use of urban public transport. There has, 
however, been difficulty in containing long-distance commuting from rural areas and market towns into cities, particularly in the South East, reflecting a historic British prejudice against apartment living. In some of these areas, it is difficult to design public transport alternatives for many commuting journeys.

Reference has already been made to the lack of discussion of mobility in relation to health and social care planning, and the same is broadly true of education. For example, the degree to which the English preference for higher education away from home continues to be sustained is likely to have significant implications for long-distance mobility demand. The pressure from international students will depend on the evolution of migration policies and the UK's economic performance. As with land-use planning and teleworking, there may also be a technological dimension if remote learning becomes more attractive.

\section{Technology Axis}

The physical infrastructure of transport networks rests on relatively mature technologies. Bridges, embankments, cuttings, pavements and trackbeds represent structures that have evolved over a very long period. Although there may be improvements in construction materials and techniques that enable them to be built more quickly, more cheaply and more durably, the basic principles are well-established and not obviously vulnerable to disruptive technologies. When it comes to considering the technological dimension of the SQF design space, then, disruptions seem more likely to affect modal choice than fundamental infrastructure. The development of self-driving cars, which might form computer-controlled road trains on motorways, could have dramatic impacts on the demand for rail transport. However, the cars would run on roads, and the trains on tracks, that would still need to be constructed to something like current standards. These new mobility technologies may have different vulnerabilities - computer-controlled road trains may be subject to disruption by solar flares interfering with GPS location tracking for example - but these affect vehicles rather than infrastructure.

Changes in energy sources may also influence modal shift. Aviation, for example, is vulnerable to shifts in the relative cost of liquid fuels because it is hard to envisage any complete substitute. Cars may become powered by fuel cells, batteries or liquid hydrogen, while rail has the advantage of electricity as its main form of energy. Electricity can be generated from a wide range of sources, with the mix varying in ways that a transport operator need not consider in detail, provided the ultimate price and supply are stable and competitive.

For truly disruptive innovations, we need to turn again to our fundamental concern with mobility. What are the technologies that might affect the demand for mobility rather than for particular journeys or forms of transport? Teleworking and 3D printing might be examples. It is possible to argue that both of these technologies have been over-hyped; nevertheless, looking ahead to 2050, both have the potential to substitute virtual for physical mobility to a considerable extent. Where physical mobility remains significant, though, this will require infrastructure constructed to meet quality and safety requirements that are unlikely to look very different from those in force today. Complying with those requirements under different climatic conditions may, of course, still dictate some technological development so that slopes remain stable with higher rainfall or pavements can cope with greater extremes of temperature.

\section{Climate Axis}

From the perspective of our case study, the main source of disruption in the SQF space is the weather. This is the short-run expression of changes in climate, which constitutes the third 
dimension of the matrix. Although it is weather events that disrupt specific journeys, infrastructure planning needs to be concerned with the likelihood that they will occur. Changes in climate alter these probabilities and are identified, in part, by inference from the difference between the expected and observed frequencies of such specific events.

The SQF approach uses projections produced within the FUTURENET project as constraints on the depiction of weather events in any particular scenario. While events outside the ranges presented here are theoretically possible, they are sufficiently implausible as to be reserved for scenarios that are being specifically developed to test for low-incidence, high-impact events rather than for those that capture the greater part of the design space. This space now needs to be populated by human actors making mobility choices within the specified constraints.

\subsection{The survey instrument and data analysis}

Discrete choice stated preference experiments are a powerful tool to analyse consumer behaviour. They were developed within transportation economics and marketing [35-37], then extended to environmental [38] and health economics [39], among other applied disciplines. This survey-based method models preferences for goods that are described by their attributes and the levels that these attributes may take [38], and it is a form of experimental choice analysis, which is "an extension to econometric and psychometric analyses of observational choice data" [40:91]. The methodology has a strong basis in Lancaster's theory of value [41]. As operationalized, individuals are asked to choose between alternatives described by attributes under different levels. Various econometric techniques are then used to assess the influence of these attributes, examine their relative importance in determining preferences and, as a result, to estimate their perceived value [42]. This allows the analyst to test a variety of scenarios and combinations of situations and variables not (or not yet) observed in reality and to estimate the way consumers may react to them.

An internet-based survey instrument was developed from two of the FUTURENET workshops mentioned above (March 2010, January 2011), whose participants included recognized experts in both travel behaviour and Social Network Analysis, and two pilot tests (November/December 2010 and April 2011). The main survey was distributed between August 2011 and February 2012, to over 2,000 respondents, split equally between the UK cities of London and Glasgow. We focus here on the interactive choice component investigating mode choice under different extreme weather conditions as associated with some socio-economic characteristics of the respondents.

Normally, the utility for any alternative $j$ has been considered as composed of a systematic component $V_{j}$ and a stochastic error term $\varepsilon$, in accordance with the random utility model [43], as follows:

$U_{j}^{n}=V_{j}^{n}+\varepsilon_{j}^{n}$

If we consider $V_{j}^{n}=\beta X_{j}^{n}$ where $\beta$ is a vector of parameters to be estimated (which include decision makers and choice alternative characteristics) and that the random errors $\varepsilon$ are independently and identically Extreme Value Type 1 distributed, we obtain the classic Multinomial Logit model, which explains the probability of selecting the alternative $j$ over another alternative $i$ within a finite choice set $C[43,44]$ : 


$$
P_{j}^{n}=\frac{\exp \left(\mu \beta^{\prime} X_{j}^{n}\right)}{\sum_{i \in C} \exp \left(\mu \beta^{\prime} X_{i}^{n}\right)}
$$

In the specification described in Equation (3), an individual $n$ chooses a transportation mode (either bus, private car or train, for example) on their own, basing this choice on the characteristics of the alternatives that compose the available choice set (they may consider travelling time, price, frequency of service, comfort, etc.). The characteristics of the decision maker $n$ may also enter the utility function in the vector $X$ to control for population heterogeneity, while $\mu$ is a scale factor.

The choice cards that respondents faced in the stated preference section of our questionnaire depicted hypothetical travel situations first described in terms of the purpose of the trip, its importance (on a scale of 0 to 10), the persons (if any) travelling with the respondents, and the weather conditions on the day of travelling, randomly chosen between 'general fine weather' and a number of Met Office extreme weather alerts. These alerts included 'heavy snow', 'very low temperatures', 'high winds', 'dense fog', 'heavy rain', and three 'extreme heat', with temperatures of 30, 33, and 36 degrees Celsius. Subsequently, four different methods of travel (Air, Train, Car, Coach) were compared based on five attributes, and respondents were asked to select their favourite one, or to state their intention of not to travel, given the conditions depicted by the choice card. The attributes were departure time, access time to the transport terminal from home, normal duration of the trip, cost of the trip, likelihood of arriving early, likelihood of arriving on time, likelihood of two delay levels (up to 5 hours), and egress time (time to reach the final destination once in London or Glasgow) ${ }^{1}$. The way possible delays were described is similar to that proposed by Li et al. [45] in their analysis of drivers' choice between two different routes, extended here to multi-modal long distance travel and with a larger number of delay indications. Although we do refer to general travel behaviour under uncertainty, our approach actually considers a choice under risk as respondents were given probabilities levels for a certain number of events. Importantly, the choice cards simulated travel choices taken fairly close to the departure time, close enough to have precise (or at least very credible) weather forecasts for the day of travel. The choice cards were created in accordance with the D-optimality experimental design principle [46] using the software N-Gene. Eight different choice cards were distributed to each respondent. An example of a choice card is illustrated below.

\footnotetext{
${ }^{1}$ The complete list of attributes and levels used in this experiment is reported in the appendix
} 
Table 1. Example of choice card

\begin{tabular}{|c|c|c|c|c|c|}
\hline & Air & Train & Car & Coach & \multirow{10}{*}{$\begin{array}{l}\text { WOULD } \\
\text { NOT } \\
\text { TRAVEL }\end{array}$} \\
\hline Departure time & $\begin{array}{l}\text { Morning } \\
\text { (between } \\
6 \mathrm{am} \text { and } \\
12 \mathrm{pm} \text { ) }\end{array}$ & $\begin{array}{l}\text { Night (after } \\
\text { 9pm) }\end{array}$ & & $\begin{array}{l}\text { Afternoon } \\
\text { (between } \\
12 \mathrm{pm} \text { and } \\
5 \mathrm{pm} \text { ) }\end{array}$ & \\
\hline $\begin{array}{c}\text { Time taken to reach } \\
\text { airport, railway or } \\
\text { coach station + waiting } \\
\text { time }\end{array}$ & $\begin{array}{l}2 \text { hours and } \\
30 \text { minutes }\end{array}$ & $\begin{array}{l}1 \text { hour and } \\
15 \text { minutes }\end{array}$ & & 1 hour & \\
\hline $\begin{array}{c}\text { Time taken for the } \\
\text { journey in normal } \\
\text { conditions }\end{array}$ & $\begin{array}{l}1 \text { hour and } \\
30 \text { minutes }\end{array}$ & $\begin{array}{l}3 \text { hours and } \\
30 \text { minutes }\end{array}$ & $\begin{array}{l}6 \text { hours and } \\
30 \text { minutes }\end{array}$ & $\begin{array}{l}9 \text { hours and } \\
30 \text { minutes }\end{array}$ & \\
\hline $\begin{array}{l}\text { Cost - single ticket, and } \\
\text { other costs to reach } \\
\text { your final destination } \\
\text { for Air/Train/Coach; } \\
\text { fuel, parking and } \\
\text { motorway tolls for cars }\end{array}$ & $£ 170$ & $£ 40$ & $£ 210$ & $£ 60$ & \\
\hline \multirow{4}{*}{ And you have: } & $\begin{array}{c}0 \% \\
\text { probability } \\
\text { of arriving } \\
10 \text { minutes } \\
\text { early } \\
\end{array}$ & $\begin{array}{c}10 \% \\
\text { probability } \\
\text { of arriving } \\
20 \text { minutes } \\
\text { early } \\
\end{array}$ & $\begin{array}{c}0 \% \\
\text { probability } \\
\text { of arriving } \\
40 \text { minutes } \\
\text { early } \\
\end{array}$ & $\begin{array}{c}0 \% \\
\text { probability } \\
\text { of arriving } \\
20 \text { minutes } \\
\text { early }\end{array}$ & \\
\hline & $\begin{array}{c}10 \% \\
\text { probability } \\
\text { of arriving } \\
\text { on time } \\
\end{array}$ & $\begin{array}{c}0 \% \\
\text { probability } \\
\text { of arriving } \\
\text { on time }\end{array}$ & $\begin{array}{l}0 \% \\
\text { probability } \\
\text { of arriving } \\
\text { on time }\end{array}$ & $\begin{array}{l}10 \% \\
\text { probability } \\
\text { of arriving } \\
\text { on time }\end{array}$ & \\
\hline & $\begin{array}{c}50 \% \\
\text { probability } \\
\text { of arriving } \\
45 \text { minutes } \\
\text { late } \\
\end{array}$ & $\begin{array}{c}60 \% \\
\text { probability } \\
\text { of arriving } \\
30 \text { minutes } \\
\text { late } \\
\end{array}$ & $\begin{array}{c}50 \% \\
\text { probability } \\
\text { of arriving } 1 \\
\text { hour and } 30 \\
\text { minutes late } \\
\end{array}$ & $\begin{array}{c}60 \% \\
\text { probability } \\
\text { of arriving } 1 \\
\text { hour late }\end{array}$ & \\
\hline & $\begin{array}{c}40 \% \\
\text { probability } \\
\text { of arriving } 5 \\
\text { hours late }\end{array}$ & $\begin{array}{c}30 \% \\
\text { probability } \\
\text { of arriving } 4 \\
\text { hours and } 30 \\
\text { minutes late } \\
\end{array}$ & $\begin{array}{l}50 \% \\
\text { probability } \\
\text { of arriving } 3 \\
\text { hours late }\end{array}$ & $\begin{array}{c}30 \% \\
\text { probability } \\
\text { of arriving } 2 \\
\text { hours and } 30 \\
\text { minutes late }\end{array}$ & \\
\hline $\begin{array}{l}\text { Time to reach your } \\
\text { destination once } \\
\text { arrived (this includes } \\
\text { additional waiting time } \\
\text { for disembarkment }\end{array}$ & 1 hour & 40 minutes & & 20 minutes & \\
\hline
\end{tabular}

The data obtained from the choice cards enabled us to estimate coefficients for the various context (reason, importance, companionship and weather) and choice attributes variables. Importantly, the attributes describing the probability of different travel times entered the utility function as the expected value of schedule delay (ESDL) or schedule early (ESDE), obtained by multiplying the different value of delay or earliness for the respective probabilities [45]. All attributes were made alternative-specific in order to detect their effect on the different modes. 
These data were interrogated in response to a number of scenarios created by the SQF component and then disrupted by the injection of weather-related journey disruption. In this case study we examine the specific responses of two travellers to each scenario. Each traveller represents a cluster of respondents (described in the following section), and their travel situations. The identification of these clusters led, in turn, to some further modifications of the original scenarios.

For simplicity, we ran Multinomial Logit over the choice cards faced by the respondents in the relevant clusters. We included in the estimated utility function the context variables and the choice attributes, while we considered the socio-economic characteristics of the respondents through the use of the clusters.

We estimated a number of models, and their results are shown in the appendix in Table A3 (an explanation of the variables is provided in Table A2). The models were run over subsamples comprising of respondents from the specific clusters used in the scenarios, as well as over the subsamples London and Glasgow, which were used for comparison. Results from the whole sample estimation are also shown in the last column in Table A3 for information. Results from the larger samples (London, Glasgow and total) show a considerable number of significant coefficients, demonstrating therefore that the vast majority of attributes and context variables were indeed determinants of the probability to select one or the other method of travel in the choice cards. In particular, coefficients describing the impact of extreme weather conditions were generally highly significant. Estimation from the different clusters showed fewer significant variables (this was however expected given the smaller size of the samples) but still an adequate number to perform the subsequent simulation exercise. In this case as well, weather variables' coefficients were generally highly significant.

Once the models were estimated, we applied restrictions to the variables entering the utility function in order to simulate the effect of the general travel conditions, disruption conditions (for example in terms of magnitude and probability of delay for the different modes, and extreme weather alert) and specific travel situations (like companionship, reason and importance), as described by the scenarios, on the possible choice of method of travel within the cluster. For example, if the scenario description involved a train trip from London to Glasgow, carried out with children, likely to last for 4 hours under snow conditions, the corresponding (alternative specific, i.e. depending on the mode) variables WCHLD (with children), DURAT (duration of the trip) and SNOW were fixed at 1 (to indicate presence of children), 4 hours (for the duration of the trip), and 1 (to indicate the extreme weather alert 'Snow'), respectively. The same was applied to some of the other variables, and methods of travel, depending on scenario description. We also carried out the simulations considering the same travel situations but in conditions of fine weather and no disruption (no delays).

The results of this simulation exercise, presented in Section 3 after each scenario description, show the share for each method of travel, including for the case of no travel, under the conditions depicted by the scenarios for the particular cluster of respondents. These shares represent the number of choice situations (out of a possible one hundred) in which a particular method, or the option of not travelling, would be chosen under the disrupted conditions for the respondents belonging to the cluster. These are then compared with the method of travel choices for the same cluster of respondents in the case of fine weather and no disruptions. The same two sets of results, disruption and fine weather, are also reported for the whole sub-samples London or Glasgow (depending on whether the cluster is taken from the London or Glasgow subsample) for comparison. 


\subsection{Sample characteristics and descriptive statistics}

After a number of thorough checks (on consistency across sections and engagement with the survey), the usable dataset was composed of 2,027 respondents with the following geographical spread: 1,037 from London: 248 from the borough of Barking \& Dagenham with Newham, 250 Barnet, 209 City of Westminster, 330 Merton with Wandsworth; and 990 from Glasgow. The sample was composed of $41 \%$ males, $59 \%$ females, with an average age of 43 . In terms of working status, $50 \%$ of respondents are working full time, $11 \%$ part-time, $10 \%$ are retired, $6 \%$ self-employed, $6 \%$ are in education.

With this survey we collected a large amount of information about the respondents, including socio-economic characteristics, current travel behaviour, attitudes towards travel, its environmental impact, climate change, as well as information about respondents' social networks (number of close contacts and their characteristics, frequency of contact, means and location). Given the vast amount of information, it was considered appropriate to generate similar-sized groups of between 50 and 250 individuals (between five and ten group solutions), using cluster analysis. A hierarchical technique of clustering (Ward's method) was applied, as it is the only one to permit categorical data. [for more information please see 47]. For the London and Glasgow samples, seven socio-demographic and social network variables were input: age, gender, status (in employment or not), children in household, ethnic origin (white or non-white), size of the respondent's social network, and the number of the members of the respondent's social network living within the local neighbourhood. An additional variable was input into the London analysis, the sub-area in which the respondent resides. The key characteristics of the final population segments, 10 for London and 8 for Glasgow, are shown in Table 2 below, with the proportion that make at least one trip between the two cities per year in bold italics. The clusters identified below were then employed in the scenario simulations.

Table 2. Key characteristics of the population segments in London and Glasgow

\begin{tabular}{|l|l|l|l|}
\hline Group & $\mathbf{N}$ (\%) & $\begin{array}{l}\text { \% more than } \\
\text { 1 trip per year } \\
\text { between the } \\
\text { cities }\end{array}$ & Key characteristics (including \% within group) \\
\hline LONDON & $\begin{array}{l}67 \\
(6.5 \%)\end{array}$ & $\mathbf{6 . 0 \%}$ & $\begin{array}{l}\text { Particularly old (63\% over 50), many non-working (40\%), group with } \\
\text { most respondents without children (90\%), and group with most white } \\
\text { respondents (93\%). }\end{array}$ \\
\hline 2 & $\begin{array}{l}211 \\
(20.3 \%)\end{array}$ & $\mathbf{8 . 5 \%}$ & $\begin{array}{l}\text { Group considered to have the most typical or 'average' characteristics } \\
\text { within the London sample (i.e. without particularly high or low values } \\
\text { for all of the variables when compared against the other groups } \\
\text { generated). }\end{array}$ \\
\hline 3 & $\begin{array}{l}155 \\
(14.9 \%)\end{array}$ & $\begin{array}{l}\text { Highest male group (52\%), group with the fewest contacts within their } \\
\text { social network (85\% have 0 or 1 contact) \& in local neighbourhood } \\
\text { (90\% have no neighbourhood contacts), and the highest proportion of } \\
\text { non-white respondents (32\% - the remainder are white). }\end{array}$ \\
\hline 4 & $\begin{array}{l}139 \\
(13.4 \%)\end{array}$ & $\begin{array}{l}64 \\
(6.2 \%)\end{array}$ & $\begin{array}{l}\text { Joint highest female group (71\%), and group with the most contacts } \\
\text { within their social network (66\% have 12 or more contacts). }\end{array}$ \\
\hline 5 & $\begin{array}{l}96 \\
(9.3 \%)\end{array}$ & $\begin{array}{l}\text { Over half (56\%) live in Barnet, many are non-working (41\%), and has } \\
\text { the most number of contacts within the local neighbourhood (all had 5 } \\
\text { or more contacts within the local neighbourhood). }\end{array}$ \\
\hline 7 & $\begin{array}{l}65 \\
(6.3 \%)\end{array}$ & $\begin{array}{l}\text { Group with the highest proportion of respondents with children (47\% } \\
\text { have at least one child). }\end{array}$ \\
\hline
\end{tabular}




\begin{tabular}{|c|c|c|c|}
\hline 8 & $\begin{array}{l}114 \\
(11.0 \%)\end{array}$ & $11.4 \%$ & $\begin{array}{l}\text { All live in Merton with Wandsworth and many are young-to-middle } \\
\text { aged (41\% aged 25-34). }\end{array}$ \\
\hline 9 & $\begin{array}{l}70 \\
(6.8 \%)\end{array}$ & $5.7 \%$ & $\begin{array}{l}\text { All live in Merton with Wandsworth, have low numbers of contacts } \\
\text { within their social network ( } 77 \% \text { have } 0 \text { or } 1 \text { contact) \& in local } \\
\text { neighbourhood ( } 81 \% \text { have no neighbourhood contacts). }\end{array}$ \\
\hline 10 & $\begin{array}{l}56 \\
(5.4 \%)\end{array}$ & $1.8 \%$ & $\begin{array}{l}\text { All live in Merton with Wandsworth and is the joint highest female } \\
\text { group (71\%). }\end{array}$ \\
\hline Total & $\begin{array}{l}1,037 \\
(100.0 \%)\end{array}$ & $8.0 \%$ & \\
\hline \multicolumn{4}{|c|}{ GLASGOW } \\
\hline 1 & $\begin{array}{l}100 \\
(10.1 \%)\end{array}$ & $41.0 \%$ & $\begin{array}{l}\text { Group with most non-workers (43\%), a high number of social network } \\
\text { contacts (all have at least } 9 \text { contacts in their social network) \& in the } \\
\text { local neighbourhood ( } 92 \% \text { have at least } 4 \text { contacts within the local } \\
\text { neighbourhood) and has the highest proportion of respondents (joint } \\
\text { with group 5) with children ( } 32 \% \text { have at least one child). }\end{array}$ \\
\hline 2 & $\begin{array}{l}101 \\
(10.2 \%)\end{array}$ & $61.4 \%$ & $\begin{array}{l}\text { Particularly young (53\% aged } 17-34), \& \text { female (69\%) group, with } \\
\text { most respondents without children (83\%) and a high number of social } \\
\text { network contacts (all have at least } 9 \text { contacts in their social network), } \\
\text { although many of these contacts are not in the local neighbourhood } \\
\text { ( } 70 \% \text { have } 0 \text { or } 1 \text { contact within the local neighbourhood). }\end{array}$ \\
\hline 3 & $\begin{array}{l}159 \\
(16.1 \%)\end{array}$ & $36.5 \%$ & $\begin{array}{l}\text { Group with the highest proportion (joint with group 8) of white } \\
\text { respondents }(90 \%)\end{array}$ \\
\hline 4 & $\begin{array}{l}153 \\
(15.5 \%)\end{array}$ & $40.5 \%$ & $\begin{array}{l}\text { Group with the highest proportion of females (70\%) and workers } \\
(74 \%) \text {. }\end{array}$ \\
\hline 5 & $\begin{array}{l}167 \\
(16.9 \%)\end{array}$ & $38.9 \%$ & $\begin{array}{l}\text { Group with the lowest number of individuals within their social } \\
\text { network (all have } 2 \text { or fewer contacts) and has the highest proportion } \\
\text { of respondents (joint with group 1) with children ( } 32 \% \text { have at least } \\
\text { one child). }\end{array}$ \\
\hline 6 & $82(8.3 \%)$ & $30.5 \%$ & $\begin{array}{l}\text { Group considered to have the most typical or 'average' characteristics } \\
\text { within the Glasgow sample (i.e. without particularly high or low } \\
\text { values for all of the variables when compared against the other groups } \\
\text { generated). }\end{array}$ \\
\hline 7 & $\begin{array}{l}177 \\
(17.9 \%)\end{array}$ & $34.5 \%$ & $\begin{array}{l}\text { Most male-dominated group ( } 58 \%) \text {, has the highest proportion in a } \\
\text { non-white group ( } 13 \% \text { - the remainder are white) and lowest } \\
\text { proportion of contacts within the local neighbourhood (all have } 1 \text { or } \\
\text { fewer contacts within the local neighbourhood). }\end{array}$ \\
\hline 8 & 51 (5.2\%) & $35.3 \%$ & $\begin{array}{l}\text { Most respondents (85\%) are aged 35-64, has a high proportion of } \\
\text { workers (73\%) and the highest proportion (joint with group 3) of white } \\
\text { respondents (90\%) }\end{array}$ \\
\hline Total & $\begin{array}{l}990 \\
(100.0 \%)\end{array}$ & $39.6 \%$ & \\
\hline
\end{tabular}

For the purposes of this case study we suggest that an SQF scenario exercise should consider how members of each group would experience a particular constellation of events and what this might imply for infrastructure, rather than being unduly concerned with possible shifts in the relative size of the groups. In the following illustrations, we have confined ourselves to investigating the response of two types of travellers (belonging to two clusters) for each scenario.

\section{London sample (London to Glasgow route)}

- Group 1 (6.5\% of total): Particularly old (63\% over 50), many non-working (40\%), group with most respondents without children (90\%), and group with most white respondents (93\%).

- Group 6 (9.3\%): Group with the highest proportion of respondents with children (47\% have at least one child). 


\section{Glasgow sample (Glasgow to London route)}

- Group 5 (16.9\% of total): Group with the lowest number of individuals within their social network (all have 2 or fewer contacts) and has the highest proportion of respondents (joint with group 1) with children (32\% have at least one child).

- Group 8 (5.2\%): Most respondents (85\%) are aged 35-64, has a high proportion of workers (73\%) and the highest proportion (joint with group 3 ) of white respondents (90\%).

\section{Illustrative scenarios and simulations}

This section illustrates the process of combining the qualitative and quantitative components of our approach to generate scenarios which may then be used in public deliberation and policymaking. We present three examples to show how different versions of the future can be created and explored but, in principle, these could be adapted or multiplied to investigate any part of the design space that is of particular relevance to citizens and stakeholders. They are not predictions about the future so much as descriptions of possibilities that are grounded in robust data about choice-making under a range of empirically realistic constraints. Scenarios 1 and 3 use the two groups from the London sample, whilst Scenario 2 uses the two groups from the Glasgow sample. In each case, the scenario context is established, an actor representative of one of the groups identified by the cluster analysis is placed into the scenario and a narrative constructed from the evidence about their most probable decisions.

\section{Scenario 1: London sample - London to Glasgow route}

This projects a future of low economic and population growth in the UK to 2050 with limited immigration. There is a limited investment in technology. However, rapid growth in the global economy has generated climate change on a high temperature pathway.

\section{Dimensions}

Society

Demography: The UK has followed a low population growth pathway to 2050 with a population just a little over 70 million, of whom about 28 per cent are over the age of 65 . This slow growth is the result of a low birth-rate, reflecting the economic uncertainty of the home population, and the unattractiveness of the country to migrants because of the sluggish economy and restrictive immigration policies to protect UK workers from competition. Migrants tend to be younger than established resident populations and to have higher birth rates so the effect of low migration on the age structure of the population is compounded.

Economy: The UK economy has been slow to recover from the crash of 2008, which resulted in more than a decade of near-zero growth, with few exceptions, compared with a historic trend of around 2.3 per cent. Subsequent growth has been slowed by the lack of domestic or international investment during that decade which has hampered the UK's ability to participate in the subsequent global recovery. International investment has been limited by the UK's disengagement from the European Union, where German leadership has gradually established a prosperous, high-skill, high-investment central zone. Multi-national companies have generally preferred to locate there, with surrounding areas, including the UK, characterized by low-skill sub-contractors.

Culture: The historic preference of the English for individualist values has created significant tensions within the UK. Although the Celtic nations have not opted for full independence, 
they operate with a high degree of economic devolution that has sustained more collective approaches to public goods and contained the extremes of social differentiation that have emerged in England. The English response to difficult economic circumstances has been for each citizen to seek to retain what they have personally rather than to contribute to universal benefits or social insurance, which have become increasing restricted to a minimal safety net.

\section{Technology}

The lack of economic growth has constrained investment in new technology and the LondonGlasgow route corridor is still operating predominantly on the infrastructure that existed in 2010, with only routine maintenance and replacement. Some rail services continue to be worked by Pendolino stock that is fifty years old and prone to failure. Although High Speed 2 (HS2) was constructed as far as Birmingham, funds were not available to support its further extension and the Scottish government had other priorities, particularly in the upgrading of its own internal links and in developing a new hub airport to enhance its links with Mainland Europe and expanding international markets. There has been substantial development of guided motor vehicle technology elsewhere but the capital requirements for the control systems and the replacement or retro-fitting of vehicles have limited its adoption to affluent commuter areas in the Southeast and it is not a factor on this route corridor.

\section{Climate}

The UK met its 2030 carbon targets mainly as a result of low economic activity and continued along a low emission pathway to 2050. The resurgent world economy has, however, struggled to check carbon emissions and the result has been a high-growth pathway that has submerged the UK's achievement.

\section{Narrative}

It is 19:00 on a Friday evening early in April 2050 at New Euston station. One side of the station is fenced off for HS2 passengers, taking the commuter route to Birmingham. If you have an HS2 ticket, you can pass from the entrance shopping mall through the barrier to the glazed waiting areas and cocktail bars. Most of the passengers are commuters heading for stations out towards the South Midlands but some are waiting for the long-haul early evening train to Glasgow, due to arrive just before midnight, although it is often 30-40 minutes late because of track or signalling failures from the ageing equipment. It has been raining all day, raising ground water levels to saturation point, and an extreme weather alert 'heavy rain' is now in place. The information display shows that incoming trains are being delayed by up to two hours because of flooding in the Carlisle area. Passengers are advised to consider travelling from Kings Cross but warned that there are also delays on that route because of flooding around York. The display changes to show that the 19:30 is not now expected to depart until about 21:00 because of delays to the incoming set. There are no reported delays on the motorways and there is a possibility of getting onto a flight by taking the HS2 premium link to Heathrow Airport and buying a walk-on ticket, although seats are selling out fast and the additional cost, compared to a rail ticket, will be substantial.

\section{Traveller Experience}

Group 1: David and Fiona McTaggart are a retired couple in their early seventies and moved to London more than fifty years ago. Fiona's sister has been ill for several years so they have been regular travellers on this route, although their low income means they normally plan carefully to obtain cheap but non-refundable tickets. The sister died last night and they have 
decided to travel today in order to attend her funeral on the day after tomorrow. They are now at home checking the various alternatives. They own a car but dislike using this for longdistance driving, so they are not considering driving among their options.

Group 6: Elspeth Wicks is a woman in her late twenties who want to travel with her two children, aged six and nine, to visit her parents for the last few days of the school holidays. It is a last minute decision as the children have strongly expressed their wish to spend a couple of days with their grandparents, whom they have not seen for a while. Elspeth would like to leave in the evening so that she could complete a day at work and collect the children from their after-school minder. The family belong to a car-share network, which they use quite heavily, but Elspeth normally prefers the train because she does not want a long drive with the children at the end of her working week. Elspeth is currently at work and she is checking the various alternatives for her trip.

These travellers are making very last minute decisions for some important trips. What are the consequences of the rail infrastructure failure for the clusters of travellers they belong to?

\section{Results of the simulations}

The following values were imposed on the variables estimated over the choice cards faced by Group 1 of the London sample:

- The Car alternative was eliminated, as our travellers do not consider using the car among their possible alternatives.

- Departure time Evening was fixed at 1, to indicate a departure in the evening.

- Cost for Air was multiplied by 1.5, to better reflect the difference between the costs of the different methods.

- Expected Standard Deviation Lateness (ESDL) for Train was fixed at the value of 152. This describes a $70 \%$ probability of a service being 2 hours delayed at destination, and 30\% probability of a 4 hour delay.

- Expected Standard Deviation Lateness (ESDL) for Air was fixed at the value of 20. This describes a $100 \%$ probability of a service being 20 minutes delayed at destination.

- Access Time (to Rail or Coach Station and Airport) was multiplied by 1.5 to reflect the likely additional time needed to reach the terminals given the weather situation.

- Extreme weather alert 'Heavy Rain' dummy variable was fixed at one.

- Importance of the trip was fixed at 10, and the variables for travelling with other adults and for visiting friends and relatives were both fixed at one.

Table 3 below reports the results of this simulation. 
Table 3. Results of Scenario 1 simulation - Group 1, 536 obs. - London total, 8296 obs.

\begin{tabular}{|c|c|c|c|c|c|c|}
\hline Choice & $\begin{array}{l}\text { \% Share } \\
\text { Scenario } 1 \\
\text { Group } 1\end{array}$ & $\begin{array}{l}\text { \% Share } \\
\text { Fine weather } \\
\text { Group } 1\end{array}$ & $\begin{array}{l}\text { Difference } \\
\text { between } \\
\text { disruption } \\
\text { scenario } \\
\text { and fine } \\
\text { weather } \\
\text { simulations }\end{array}$ & $\begin{array}{l}\text { \% Share } \\
\text { Scenario } \\
1 \\
\text { London } \\
\text { resp. }\end{array}$ & $\begin{array}{l}\text { \% Share } \\
\text { Fine } \\
\text { weather } \\
\text { London } \\
\text { resp. }\end{array}$ & $\begin{array}{l}\text { Difference } \\
\text { between } \\
\text { disruption } \\
\text { scenario } \\
\text { and fine } \\
\text { weather } \\
\text { simulations }\end{array}$ \\
\hline AIR & 48.061 & 58.251 & -10.19 & 17.191 & 25.629 & -8.438 \\
\hline TRAIN & 29.991 & 23.614 & 6.377 & 45.875 & 40.787 & 5.088 \\
\hline CAR & - & & & 12.433 & 19.826 & -7.393 \\
\hline $\mathrm{COACH}$ & 5.610 & 12.228 & -6.618 & 5.886 & 6.621 & -0.735 \\
\hline NO TRAVEL & 16.338 & 5.907 & 10.431 & 18.616 & 7.136 & 11.480 \\
\hline Total & 100.000 & 100.000 & & 100.000 & 100.000 & \\
\hline
\end{tabular}

Table 3 shows that the disruptions would make respondents in group 1 (such as David \& Fiona McTaggart) to decide not to travel in an extra $10 \%$ of choice situations, despite the high importance of the trip. The disruptions would particularly hit coach and air travellers, while more people would choose to travel by train despite the delays. A similar situation would apply when the scenario conditions are tested for the London sample.

For group 6 (e.g. Elspeth Wicks), the same restrictions to the variables illustrated above were applied. The only difference was relative to the companionship, with the variable indicating the situation of travelling with children fixed at 1 , and the importance of the trip fixed at 7 rather than 10 . Table 4 below illustrates the results of this simulation.

Table 4. Results of Scenario 1 simulation - Group 6, 768 obs. - London total, 8296 obs.

\begin{tabular}{|c|c|c|c|c|c|c|}
\hline Choice & $\begin{array}{l}\text { \% Share } \\
\text { Scenario } \\
1 \\
\text { Group } 6\end{array}$ & $\begin{array}{l}\text { \% Share } \\
\text { Fine } \\
\text { weather } \\
\text { Group } 6\end{array}$ & $\begin{array}{l}\text { Difference } \\
\text { between } \\
\text { disruption } \\
\text { scenario } \\
\text { and fine } \\
\text { weather } \\
\text { simulations }\end{array}$ & $\begin{array}{l}\text { \% Share } \\
\text { Scenario } \\
1 \\
\text { London } \\
\text { resp. }\end{array}$ & $\begin{array}{l}\text { \% Share } \\
\text { Fine } \\
\text { weather } \\
\text { London } \\
\text { resp. }\end{array}$ & $\begin{array}{l}\text { Difference } \\
\text { between } \\
\text { disruption } \\
\text { scenario } \\
\text { and fine } \\
\text { weather } \\
\text { simulations }\end{array}$ \\
\hline AIR & 21.433 & 31.727 & -10.294 & 14.033 & 13.133 & 0.900 \\
\hline TRAIN & 29.189 & 39.376 & -10.187 & 41.353 & 43.280 & -1.927 \\
\hline CAR & - & & & 11.367 & 17.851 & -6.484 \\
\hline $\mathrm{COACH}$ & 6.444 & 12.549 & -6.105 & 7.365 & 12.990 & -5.625 \\
\hline $\begin{array}{l}\text { NO } \\
\text { TRAVEL }\end{array}$ & 42.934 & 16.348 & 26.586 & 16.140 & 12.746 & 3.394 \\
\hline Total & 100.000 & & & 100.000 & 100.000 & \\
\hline
\end{tabular}


The disruptions described by scenario 1 would have a considerably greater effect than for the previous group, with an additional $26 \%$ of choice cards where respondents would decide not to travel given the weather and disruptions, making the No Travel option to be chosen in almost $43 \%$ of choice cards. The lower importance of the trip, and the presence of children, may be the main determinants of this impact. All methods of travel would lose preferences. The same disruptions would have a much weaker effect on the whole London sub-sample, with only $4 \%$ of additional preferences for No Travel.

Under this range of conditions, then, we are led to a vision of the future where we could expect to see the first type of passenger being very likely to continue their journey, and to be supplemented by others switching to rail from coach and air, while the second type would be much more likely to abandon their journey. Stakeholders can now be asked how desirable they think these outcomes would be and whether they would wish to prevent them.

\section{Scenario 2: Glasgow sample - Glasgow to London route}

This projects a future of high economic growth and population growth in the UK to 2050 . However, international agreement and technological innovation has held climate change on a relatively low temperature pathway.

\section{Dimensions}

\section{Society}

Demography: The UK has followed a high population growth pathway to 2050 with a population approaching 85 million, of whom about 21 per cent are over the age of 65 . This rapid growth is mainly the result of the country's attractiveness to migrants because of its vibrant economy.

Economy: The UK economy was slow to recover from the crash of 2008, which resulted in a decade of near-zero growth, compared with a historic trend of around 2.3 per cent. However, a shift in economic policy, emphasising investment in infrastructure renewal and green technologies, had strong multiplier effects and led to a period of above-trend growth. This has since subsided somewhat but has still left the UK in a stronger position than many European countries. The economic boom led to significant labour shortages, which were filled partly by technological developments in areas like telecare, and partly by immigration of skilled workers. Although there are still tensions with other members of the EU, with competition for inward investment and international markets, these are generally acknowledged to be minor when set against the prolonged period of growth and stability that has been achieved through joint actions.

Culture: The historic preference of the English for individualist values was reappraised after the experience of the banking crisis and the observable success of the Celtic nations in attracting high-quality science and technology businesses through a combination of public investment and public services that created an environment in which emerging entrepreneurs wanted to sustain family lives. There was also a frank acknowledgement of the greater success of the German model of economy and society since the 1960s. This had resulted in structural and constitutional changes that had greatly empowered regional governments and focussed planning on much longer time horizons. Although these changes were not popular with the losers, particularly in the Southeast of England, they had reflected a more selfconsciously communitarian approach to considering the costs and benefits of decisions within a wider context. 


\section{Technology}

There has been substantial investment in transport technology, although this has had a strong emphasis on public provision. The former West Coast mainline had an extensive programme of work to remove bottlenecks as part of the initial phase of rapid minor improvements, but is now mainly used for suburban and inter-regional journeys. HS2 is well-established as the express route between London and Glasgow, thanks to Scottish and European investments complementing those of the UK government. The European investment was part of a plan to bear down on the use of air travel within the continent in order to reduce carbon emissions and to reserve this mode for those long-haul journeys where it had a clear comparative advantage. Air passenger and freight journeys of less than 400 miles (slightly below the distance London - Glasgow) are now subject to prohibitive tax rates and taxes have been considerably raised for all other flights within Europe. There has been an associated investment in rail/air interchange at selected hub airports that have been designated as European Interchanges, with long-haul passengers transferring to rail rather than feeder flight networks. Long-distance bus and coach services are still important but there is less of a price gap because of the rising cost of diesel, even from biofuel sources, reflecting carbon taxes and supply constraints. Since a certain level of mobility is viewed as a public good, subsidies ensure that rail fares for long distance domestic journeys remain competitive with road and longer distance air, even on HS2 services.

\section{Climate}

A series of major storm events that devastated the low-lying coasts of the eastern USA and southern China between 2020 and 2030 brought an important geopolitical shift on the control of carbon emissions, although some members of the US Congress continued to regard the storms as Divine judgement on Sodom and Gomorrah. While the US had become largely self-sufficient in energy through fracking technologies, these had proved to be costly, inefficient and unpopular with local communities. A major global shift towards low-emission forms of energy, particularly renewables, had produced a discernible impact on climate by 2050. Although anthropogenic warming was continuing to be evident, the speed of growth had slowed and there were signs that it might begin to decline by the end of the century.

\section{Narrative}

It is 19:00 on a Friday evening early in April 2050. Different people in different locations across Glasgow are planning a trip to London in exactly a week's time. They all prefer departing in the evening, and are closely checking various options as well as the weather forecasts. Their weather forecast app also has a live webcam showing the current situation at various transport terminals across the country including Glasgow Central railway station. The historic listed building is shining from its most recent refurbishment, where the roof glazing has been replaced with self-cleaning glass panels that have photovoltaic cells embedded for solar generation. Although the light is beginning to fade, the area of glass and the efficiency of the cells mean that the station is largely self-sufficient for daytime power needs, other than traction, during most of the year.

To the left are the HS2 platforms, where the express service is waiting. On the right is a stopping service to Manchester. Although the first phase of HS2 had located stations outside cities and limited integration with services to intermediate destinations, the impact on traveller demand, local commuting and intermediate towns had been such that the later phases had created designated interchange points between express and stopping services. Our potential passengers are most interested in the HS2. It offers a high reliability service but, like 
all trains that depend on overhead electrification, is vulnerable to high winds. Although the UK climate has stabilized considerably since the 2030s, extreme weather events continue to occur, albeit less frequently. The Meteorological Office predict, with almost absolute certainty according to their models, that an Atlantic storm system will hit the Lake District area in exactly a week's time, when our people are planning to travel. The storm should hit in the morning, but its consequences on the infrastructure are likely to be felt for a couple of days afterwards. The last time a similar storm hit the same area, just a few months ago, the HS2 route had lost several hundred metres of wiring. Some works have been done, but the railway operators have admitted they are not sure the new infrastructure will mean that no disruptions will be caused by the predicted storm. The old mainline should not be affected, as it was at the time of the last storm, so the stopping service offers an alternative, which will involve changing trains at Manchester and at Leamington Spa, and will take about two hours longer.

There is still a possibility of flying from Glasgow Airport, where airlines have squeezed their margins to offset higher taxes. However there are very few seats on the mid-evening flight and these are selling out fast. There is a price war among rail operators and airlines on this particular route so that the air fare will be approximately the same as that for HS2: in this case, they have both been set at $£ 160$. The storm will cause some delays, especially to flights in the morning and early afternoon, but delays for the evening and night flights are predicted to be minor. There are no predicted delays on the motorways, and the motorway system coped fairly well when the last storm hit, as high vehicles were temporarily banned from the affected area during the period of stronger winds. The cost for this trip, which our respondents can easily calculate through their journey planner app, would be on the same level as air and rail. Another possibility is a long distance coach service from Buchanan Street Bus Station, also departing in the evening. This would be somewhat cheaper than the other options.

\section{Traveller Experience}

Group 5: Anna is a Spanish researcher at one of the universities in Glasgow, married to a Scottish vet. She is taking her children, who are 12 and 14, to visit their grandparents in San Sebastian. Because of the cost of European air travel and the family fare packages available across the whole high-speed rail network, she is considering taking the HS2 to London, where she could spend the night at a friend's house, transferring to HS1 and picking up a network of connections that will deliver her to San Sebastian the following evening in time for dinner. However, the other modes could also be an option to reach London, even using her car, which she could park at the same friend's house, and then continue by train to Spain the following morning.

Group 8: Sandy, Stuart and Iain are all dedicated Celtic supporters. Their team is playing in a Europa Cup final in London in eight days, and they are planning a trip to the capital. They are thinking of leaving after work on the previous day, as there are no seats available on planes, coaches and fast trains for the day of the final, and traffic forecast are very discouraging for considering the car on that day. They are considering all modes, apart from the slow train.

All of these travellers are now planning a trip which is likely to be disrupted. What are the consequences of the likely rail infrastructure failure for these would-be travellers?

\section{Results of the simulations}

The following values were imposed on the following variables estimated for the choice cards faced by group 5 of the Glasgow sample: 
- Departure time Evening was fixed at 1, to indicate a departure in the evening.

- Normal scheduled travel time for Train was fixed at 210 minutes, as for the case of a high speed service operating between Glasgow and London.

- Cost for Air, Train and Car was fixed at the same value of $£ 160$.

- Expected Standard Deviation Lateness (ESDL) for Train was fixed at the value of 60. This roughly describes a $40 \%$ probability of a service being 30 minutes delayed at destination, 30\% probability of an hour delay, and 30\% probability of a 90 minute delay.

- Expected Standard Deviation Lateness (ESDL) for Air was fixed at the value of 20. This roughly describes a 100\% probability of a service being 20 minutes delayed at destination.

- Extreme weather alert 'Severe Gales' was fixed at one

- Importance of the trip was fixed at 7, and the variables for travelling with children and for visiting friends and relatives were both fixed at one.

Table 5 below reports the results of this simulation.

Table 5. Results of Scenario 2 simulation - Group 5, 1336 obs. - Glasgow total, 7920 obs.

\begin{tabular}{|l|r|l|l|l|l|l|}
\hline Choice & $\begin{array}{l}\text { \% Share } \\
\text { Scenario 2 } \\
\text { Group 5 }\end{array}$ & $\begin{array}{l}\text { \% Share } \\
\text { Fine } \\
\text { weather } \\
\text { Group 5 }\end{array}$ & $\begin{array}{l}\text { Difference } \\
\text { between } \\
\text { disruption } \\
\text { scenario } \\
\text { and fine } \\
\text { weather } \\
\text { simulations }\end{array}$ & $\begin{array}{l}\text { \% Share } \\
\text { Scenario 2 } \\
\text { Glasgow } \\
\text { resp. }\end{array}$ & $\begin{array}{l}\text { \% Share } \\
\text { Fine } \\
\text { weather } \\
\text { Glasgow } \\
\text { resp. }\end{array}$ & $\begin{array}{l}\text { Difference } \\
\text { between } \\
\text { disruption } \\
\text { scenario } \\
\text { and fine } \\
\text { weather } \\
\text { simulations }\end{array}$ \\
\hline AIR & 16.335 & 34.819 & -18.484 & 17.687 & 38.853 & -21.166 \\
\hline TRAIN & 45.885 & 41.729 & 4.156 & 45.107 & 34.496 & 10.611 \\
\hline CAR & 4.251 & 7.654 & -3.403 & 7.487 & 10.158 & -2.671 \\
\hline COACH & 6.703 & 11.649 & -4.946 & 10.695 & 11.525 & -0.830 \\
\hline $\begin{array}{l}\text { NO } \\
\text { TRAVEL }\end{array}$ & 26.826 & 4.148 & 22.678 & 19.024 & 5.238 & 13.786 \\
\hline Total & 100.000 & 100.000 & & 100.000 & 100.000 & \\
\hline
\end{tabular}

Table 5 shows that the disruptions described in scenario 2 would make group 5 respondents (e.g. Anna) to decide not to travel in an extra $23 \%$ of choice cards, despite the relative high importance of the trip. 13\% would be the corresponding figure for the Glasgow sub-sample in the same situation. The disruptions would particularly hit air travellers, both for the case of group 5, and to a greater extent for the whole Glasgow sub-sample. The vast majority of travellers would still travel by train despite the delays, and Train would actually gain preferences.

For group 8 (Sandy, Stuart and Ian), the same restrictions to the variables illustrated above were applied. The only difference was relative to the companionship, with the variable indicating the situation of travelling with adults fixed at 1 , the importance of the trip fixed at 
9 rather than 7, and the variable indicating travelling for leisure fixed at 1 . Table 6 illustrates the results of this simulation.

Table 6. Results of Scenario 2 simulation - Group 8, 408 obs. - Glasgow, 7920 obs

\begin{tabular}{|l|r|r|l|r|l|r|}
\hline Choice & $\begin{array}{l}\text { \% Share } \\
\text { Scenario 2 } \\
\text { Group 8 }\end{array}$ & $\begin{array}{l}\text { \% Share } \\
\text { Fine } \\
\text { weather } \\
\text { Group 8 }\end{array}$ & $\begin{array}{l}\text { Difference } \\
\text { between } \\
\text { disruption } \\
\text { scenario } \\
\text { and fine } \\
\text { weather } \\
\text { simulations }\end{array}$ & $\begin{array}{l}\text { \% Share } \\
\text { Scenario 2 } \\
\text { Glasgow } \\
\text { resp. }\end{array}$ & $\begin{array}{l}\text { \% Share } \\
\text { Fine } \\
\text { weather } \\
\text { Glasgow } \\
\text { resp. }\end{array}$ & $\begin{array}{l}\text { Difference } \\
\text { between } \\
\text { disruption } \\
\text { scenario } \\
\text { and fine } \\
\text { weather } \\
\text { simulations }\end{array}$ \\
\hline AIR & 13.990 & 38.051 & -24.061 & 21.315 & 43.534 & -22.219 \\
\hline TRAIN & 55.717 & 39.979 & 15.738 & 48.678 & 34.702 & 13.976 \\
\hline CAR & 8.343 & 8.924 & -0.581 & 6.793 & 8.647 & -1.854 \\
\hline COACH & 15.258 & 11.464 & -5.206 & 9.694 & 9.736 & -0.042 \\
\hline $\begin{array}{l}\text { NO } \\
\text { TRAVEL }\end{array}$ & 100.000 & 100.000 & 14.109 & 13.520 & 3.380 & 10.14 \\
\hline Total & & & 100.000 & 100.000 & \\
\hline
\end{tabular}

Table 6 shows that the disruption would hit respondents in group 8 to a lesser extent than the previous group, with an extra $14 \%$ (rather than $23 \%$ as in the previous case) of choice cards reporting No Travel as the most likely behaviour given the conditions. Air and coach travel would be the most affected by the weather-related disruption, and to a greater extent than in the previous case, with Train much preferred at the same price than Air in the described disruptions and weather conditions. For this group, however, preferences for car travel would not be considerably affected by the disruption.

Under this range of conditions, then, we are led to a vision of the future where we could expect to see the first type of passenger being quite likely to continue their journey, and to be supplemented by others switching to rail from coach and air, while the second type would be very likely to continue their journey, again with air passengers switching to the train, despite the risks of delay. Stakeholders can now be asked how desirable they think these outcomes would be and whether they would wish to prevent them.

\section{Scenario 3: London sample - London to Glasgow route}

This projects a future of high economic and population growth in the UK to 2050. However, technological development and cultural resistance means that this has not been matched by investment in transport infrastructure. The dominance of individualism has blocked international agreement to restrain climate change, which has followed a relatively high temperature pathway. 


\section{Dimensions}

\section{Society}

Demography: The UK has followed a high population growth pathway to 2050 with a population of just over 80 million, of whom about 25 per cent are over the age of 65 . This rapid growth is mainly the result of increased longevity, resulting from the decline in smoking and alcohol consumption early in the century and changes in the industrial structure that have eliminated many formerly hazardous occupations.

Economy: The UK economy was slow to recover from the crash of 2008, which resulted in a decade of near-zero growth, compared with a historic trend of around 2.3 per cent. However, a laissez-faire economic policy eventually brought a strong bounce back through private investment, particularly as a global supplier of financial and professional services, which spilled over into demands for property, luxury goods and personal care. Servicing this group of highly paid professionals sustained a significant low-wage sector of the economy, particularly in the provision of personal services. However, many people rarely had much reason to leave their homes or immediate locality, unless they had sufficient wealth to indulge high mobility preferences and an itinerant lifestyle, logging into their professional work from wherever they happened to be at the time.

Culture: The historic preference of the English for individualist values is accommodating to the mobile professionals, since it imposes relatively few restraints on their ability to trade or to indulge their leisure preferences. However, it is recognized that the security and stability of the places that they like to occupy requires a basic level of social provision for the servant class. The aesthetic pleasures of a historic city can be ruined by people sleeping in doorways and there are costs to relying solely on private security for the safety of oneself and one's property. A reliable local public transport system means that service workers can be accommodated in other parts of the city.

\section{Technology}

High mobility business rests on remote technologies ran over a private internet, with protocols designed from the start to support authentication and security and speeds that could sustain effective virtual co-presence. This infrastructure is also well-adapted to 3D printing, which significantly reduces the requirements for manufactured goods to be delivered direct to end-users. Some products, of course, still require physical delivery services, particularly food and stocks of unprocessed or partially processed raw materials for 3D printers to work with. Investment in virtual communication and manufacturing has significantly reduced the pressure for continuing improvements in transport networks. These still have a role in offering mass transit for those working in service industries and in offering highly personalized travel for those choosing to demonstrate their wealth through mobility. This can be seen in the contrast between the intra-city private buses, driven by individual owners on the colectivo model, and the self-driving control systems that have been installed on the motorway network and some of the more affluent areas connected to it. Should an owner choose to do so, their car will transport them door-to-door over long distances in comfort, seclusion and privacy while they continue to trade or interact with co-workers online. The values of this society set personal choice and autonomy at their maximum. 


\section{Climate}

Calls for action to reduce climate change are considered to be an expression of collective interest that should be overridden by respect for personal choice. Although fast virtual communications have reduced the need to travel for business or professional purposes, they have created new opportunities to travel for pleasure. 3D printing may have reduced shipments of manufactured goods but it still requires the movement of raw or part-processed materials. Traffic flows shift, but the volume may not decline as much. In particular, personalization tends to generate additional movements - private jets rather than collective airplanes. For this group of travellers, major storm events are considered to be inconveniences rather than catastrophes - just move on and log in somewhere that is not affected. As a result, global warming has continued to accelerate along a high pathway.

\section{Narrative}

It is 15:00 on a Friday afternoon early in April 2050. A group of travellers are huddled inside the entrance to the London Gateway services at the foot of the M1. An unexpectedly intense late spring storm system, with high winds, thunderstorms and lightning, has hit Central England and temporarily closed sections of the M1/M6. A number of vehicles have been hit by lightning, causing several accidents. Even the GPS-controlled self-driving vehicles have been diverted off the road because of the difficulty of maintaining control under these conditions. No-one wants to linger here. The expansion of self-drive with door-to-door mobility in comfort levels approaching one's own living room has siphoned off the more affluent customers who used to sustain the higher-end shops and café franchises. Waitrose and Starbucks have long since departed and the services have reverted to the edgy, greasy spoon environments for which they were once notorious. A chill draught blows through the concourse every time the automatic doors open for a new traveller, stirring dust and plastic cups into corners that may or may not be cleaned later. Outside the wind whips the rain into drifts that hammer against the glass panels and aluminium roof. It has been raining for most of the last week, as evidenced by the puddles around the ageing seals on the glazing.

A few people have the wearable information devices that are common in Europe, but most have cheaper hand-held systems. The message is the same on each, however: the motorway will be closed for at least four hours while wreckages are cleared to the hard shoulder and the rain and winds are predicted to drop. The trains from New Euston are still running, although the walk-up fares are expensive and the service is slow and unreliable. While the HS2 trains run hourly to Birmingham, they were acknowledged to be white elephants and the line had never been extended. Glasgow is still served by veteran Pendolino stock scheduled to make the run in five hours- journey times have increased since the early years of the century because of the lack of infrastructure maintenance and the fragile state of some of the track. Services are often cancelled or run anything between one and three hours late. The cost is comparable to a GPS self-drive toll for the journey but about four times what it would cost for an ordinary car. Plane journeys are more expensive, if seats are available, although delays are minimal for the moment.

\section{Traveller Experience}

- Group 1: Paul and Stewart Bailey are two brothers in their early sixties who have been running a family business, located just North of London, together for almost 10 years. They sell various types of wines that are produced in different areas around Central and Northern England. Today, they are travelling to Glasgow by car to meet a 
prospective client, a buyer from a large chain of hotels and restaurants. Given the importance of the potential customers, they have decided to travel to meet her in person rather than rely on virtual meeting technology. They have also decided to travel by car to transport a number of bottles of wine with them, and then pay a visit to some of their suppliers on the way back. On some occasions they have used rail or air for business travel purposes, although the latter only when they had no (or a very limited) amount of wine with them.

- Group 6: Robert Nash is a man in his late thirties who is travelling with his two children, aged 12 and 14, to Glasgow, where they are planning to spend the night before heading onwards the following morning to the Northwest coast of Scotland. Robert and his children are keen surfers, and the storm should bring waves of up to 10 metres high. As the surfing conditions around the English coasts have been fairly poor in the last few months, they are really looking forward to riding these waves before returning to school. The family belong to a GPS-control van-share network, which they use quite heavily. Robert is using one of these vehicles because it is easy to relax and chat with his children, compared with the cramped and sometimes dirty conditions on the train. Importantly, these vans have space to transport the surfboards, and can also be for sleeping. Taking a train or flight would mean an extra cost for the surfboards, and then the necessity to hire a car in Glasgow to reach the surfing areas.

All of these travellers are now facing a significant disruption to their plans. What are the consequences of the road infrastructure failure for these would-be travellers?

\section{Results of the simulations}

The following values were imposed on the following variables estimated over the choice cards face by Group 1:

- Departure time Afternoon was fixed at 1, to indicate a departure in the afternoon.

- Normal scheduled travel time for Train was fixed at 300 minutes, as described by the scenario.

- Cost for Air was multiplied by 1.5, and cost of Train by 1.25, to indicate the extra cost in changing the method of travel.

- Expected Standard Deviation Lateness (ESDL) for Train was fixed at the value of 129. This roughly describes a $30 \%$ probability of a service being 60 minutes delayed at destination, $30 \%$ probability of a two-hour delay, 30\% probability of a 3 hour delay, and $10 \%$ probability of a 4 hour delay.

- $\quad$ Expected Standard Deviation Lateness (ESDL) for Car was fixed at the value of 250. This roughly describes a $80 \%$ probability of a 4 hour delay at destination and $20 \%$ probability of a 5 hour delay.

- Expected Standard Deviation Lateness (ESDL) for Air was fixed at the value of 20. This roughly describes a $100 \%$ probability of a service being 20 minutes delayed at destination.

- Access Time (to Rail or Coach Station and Airport) was multiplied by 2 to reflect the likely additional time needed to reach the terminals given the current location of the travellers.

- Extreme weather alert 'Thunderstorm and Lighting' was fixed at one

- Importance of the trip was fixed at 9, and the variables for travelling with adults and for business purposes were both fixed at one.

Table 7 reports the results of this simulation. 
Table 7. Results of Scenario 3 simulation - Group 1, 536 obs. - London total, 8290 obs.

\begin{tabular}{|l|r|l|l|l|l|l|}
\hline Choice & $\begin{array}{l}\text { \% Share } \\
\text { Scenario 3 } \\
\text { Group 1 }\end{array}$ & $\begin{array}{l}\text { \% Share } \\
\text { Fine } \\
\text { weather } \\
\text { Group 1 }\end{array}$ & $\begin{array}{l}\text { Difference } \\
\text { between } \\
\text { disruption } \\
\text { scenario } \\
\text { and fine } \\
\text { weather } \\
\text { simulations }\end{array}$ & $\begin{array}{l}\text { \% Share } \\
\text { Scenario 3 } \\
\text { London } \\
\text { resp. }\end{array}$ & $\begin{array}{l}\text { \% Share } \\
\text { Fine } \\
\text { weather } \\
\text { London } \\
\text { resp. }\end{array}$ & $\begin{array}{l}\text { Difference } \\
\text { between } \\
\text { disruption } \\
\text { scenario } \\
\text { and fine } \\
\text { weather } \\
\text { simulations }\end{array}$ \\
\hline AIR & 22.204 & 52.448 & -30.244 & 15.543 & 36.554 & -21.011 \\
\hline TRAIN & 47.117 & 15.931 & 31.186 & 57.984 & 33.106 & 24.878 \\
\hline CAR & 2.804 & 18.661 & -15.857 & 6.837 & 17.025 & -10.188 \\
\hline COACH & 2.089 & 8.173 & -5.084 & 3.751 & 6.319 & -2.568 \\
\hline $\begin{array}{l}\text { NO } \\
\text { TRAVEL }\end{array}$ & 100.000 & 100.000 & & 15.884 & 6.996 & 8.888 \\
\hline Total & & 4.786 & 20.000 & 100.000 & 100.000 & \\
\hline
\end{tabular}

The disruption described in Scenario 3, following the extreme weather alert 'Thunderstorm and Lighting", would, in accordance with expectations given the situation in the motorway, particularly affect car and coach travellers in Group 1 (like Paul and Stewart). However, air travellers would also be considerably affected, while Train share would considerably increase, and remain the most likely mean for travellers in group 1, and the second one in the London subsample, where Air, Coach and Car would be less affected. In a total of $25 \%$ of cases respondents in group 1 would decide not to travel as a consequence of the disruption, a $20 \%$ difference with respect to the case of fine weather, despite the high importance of the trip. A lower increase of the No Travel situation would be observed for the whole of London.

For group 6, the same restrictions to the variables illustrated above were applied. The only difference was relative to the companionship, with the variable indicating the situation of travelling with children fixed at 1 , the importance of the trip fixed at 7 rather than 9 , and the variable indicating travelling for leisure fixed at 1 . Table 8 illustrates the results of this simulation. 
Table 8. Results of Scenario 3 simulation - Group 6, 768 obs. - London total, 8290 obs.

\begin{tabular}{|l|r|l|l|l|l|l|}
\hline Choice & $\begin{array}{l}\text { \% Share } \\
\text { Scenario 3 } \\
\text { Group 6 }\end{array}$ & $\begin{array}{l}\text { \% Share } \\
\text { Fine } \\
\text { weather } \\
\text { Group 6 }\end{array}$ & $\begin{array}{l}\text { Difference } \\
\text { between } \\
\text { disruption } \\
\text { scenario } \\
\text { and fine } \\
\text { weather } \\
\text { simulations }\end{array}$ & $\begin{array}{l}\text { \% Share } \\
\text { Scenario 3 } \\
\text { London } \\
\text { resp. }\end{array}$ & $\begin{array}{l}\text { \% Share } \\
\text { Fine } \\
\text { weather } \\
\text { London } \\
\text { resp. }\end{array}$ & $\begin{array}{l}\text { Difference } \\
\text { between } \\
\text { disruption } \\
\text { scenario } \\
\text { and fine } \\
\text { weather } \\
\text { simulations }\end{array}$ \\
\hline AIR & 14.520 & 32.113 & -17.593 & 12.815 & 33.452 & -20.637 \\
\hline TRAIN & 57.615 & 34.020 & 23.595 & 53.974 & 33.310 & 20.664 \\
\hline CAR & 2.845 & 21.957 & -19.112 & 4.666 & 12.133 & -7.467 \\
\hline COACH & 22.142 & 4.819 & -2.667 & 7.100 & 12.263 & -5.163 \\
\hline $\begin{array}{l}\text { NO } \\
\text { TRAVEL }\end{array}$ & 100.000 & 100.000 & & 100.000 & 100.000 & 12.603 \\
\hline Total & 7.091 & 15.788 & 21.445 & 8.842 & \\
\hline
\end{tabular}

Scenario 3 would have a similar impact on the choice of group 6 (e.g. Robert and his children) than those of group 1. Car, which would be extremely popular among group 6 respondents in the case of fine weather, and Coach would be the most affected modes, with Air also losing a large amount of preferences. As for the case above, and similar to the London case, about $22 \%$ of respondents would decide not to travel. Under this range of conditions, then, we are led to a vision of the future where we could expect to see both types of passenger being very much less likely to continue their journey, although rail would be likely to come under pressure as passengers switch from other modes. Stakeholders can now be asked how desirable they think these outcomes would be and whether they would wish to prevent them.

As we stressed in opening this section, these specific scenarios illustrate how the elements of our approach come together and integrate different sources of data into visions of the future. The same methodology can, in principle, be used to generate other scenarios that would test other possibilities within the plausible design space. Its limitations are typical of all simulation exercises. Those specific to our methodology includes the way our experiment has been designed, the types of attributes and their levels and, in particular, the way delay levels and probability were presented to respondents. We were able to simulate travel decisions made fairly close to the departure time, which, we acknowledge, is not always the case. The socio-economic characteristics of the respondents were considered by running the simulations over specified groups identified through cluster analysis. This allowed us to use a more parsimonious model than would have been the case if we had considered those characteristics directly in the utility function. This may limit the size of the samples for statistical analysis, but our use of the identified clusters, which were built on a large number of socio-economic characteristics, including some referring to the respondents' social networks, enabled us to better specify the personal situation of the would-be travellers. This made it possible to focus on mobility demand rather than simple travel behaviour. As we were focussing on the future, it was also necessary to adopt a stated preference approach, rather than considering actual current behaviour. This may raise issues about the relationship between what people say and what they do, but we consider that it is preferable to assuming that the future will be identical to the present. 


\section{Discussion and conclusions}

This paper has demonstrated an approach to the use of scenario methods through a case study of the future resilience of the UK transport network as represented by long distance travel demand and behaviour on the corridor London-Glasgow. It systematically assembles diverse types of information to create multi-dimensional (society, technology, culture and transport infrastructure) future scenarios and simulates the impact of extreme weather related disruption on the likely behaviour of would-be travellers between the two cities. The approach integrates qualitative and quantitative methods, accommodating a more extensive set of data and other social scientific evidence on social organization. This allows transport policy makers, or other infrastructure planners, to consider a broader range of impacts and to be more transparent with respect to values, facilitating public engagement and legitimacy in decision-making. There are themes emerging with the paper, and those are discussed in what follows. First, the integration of the methods. This protocol does not produce the kind of linear, 'up and to the right' forecasts, traditionally used by transport planners but generates a range of 'what-if' situations, reflecting both qualitative and quantitative inputs, that link the supply of transport to the socially and culturally generated demand for mobility. It invites transport planners to consider the viability of infrastructure investments in relation to a range of possible futures and the diversity of mobility demands within different social groups. Such an approach is particularly important in relation to major investments that may have a replacement cycle measured in decades, if not centuries. These investments need sufficient design resilience to be relevant under a variety of possible futures, rather than embedding a single vision formulated in a particular present moment. The approach demonstrated here, being based on a large and rich dataset, has created a protocol which could easily be used to test other types of infrastructure investment. This would be possible particularly because of the way the quantitative and qualitative information are integrated in an iterative fashion. Having started with a brainstorming phase, where qualitative debates were constrained by quantitative evidence from, for example, demographic projections, we were able to define and capture relevant issues for the stated preference phase. In turn, this phase became a basis for revisiting the qualitative work, as the identified clusters of travellers and their mobility demands were recast into typical actors within the scenarios and used to depict the consequences of different possible futures.

Second, the range of impacts. The approach taken here also brings out the limitations of traditional transport behaviour studies that treat demand as a simple aggregate of individual decisions, taken in isolation from other social or cultural considerations. The stated preference component does indeed find that weather related disruption would lead to a considerable number of travellers deciding not to travel despite the importance of their trip in terms of their mobility demand. On the other hand, the majority of travellers would still choose to travel because of the subjectively compelling nature of the journey's outcome for their obligations to other social network members. Their demand needs to be acknowledged by transport infrastructure planners and policy makers. The social nature of mobility means that providers cannot assume that travellers will heed injunctions to avoid travelling in the face of forecast extreme weather disruption. A better balance needs to be struck between investment to increase travel infrastructure resilience and measures to suppress demand when disruption is anticipated. Even under extreme conditions, traveller demand only declines by relatively small amounts. While this may seem perverse from the providers' perspective, our data show that it is a rational outcome from the various social, economic and cultural influences that shape mobility. Within this context, our results show that, for the UK at least, air travel would be the mode whose demand was most affected by anticipation of extreme weather events: travellers seem to show a certain confidence in trains as the best way to reach 
their destinations in difficult weather conditions. The process of scenario construction, into which typical travellers are inserted, also requires a review of other social or socio-technical developments that may influence assumptions about mobility. Transport systems are embedded within institutional complexes that collectively shape mobility demand rather than having an autonomous role. By approaching infrastructure planning at the level of the complex rather than the individual element, alternative investments can be fully evaluated.

Third, the transparency of values. By generating outputs in a narrative format, we have also developed a powerful tool for public engagement with planning debates. Although FUTURENET was not designed to take this further step, some of the authors have previously undertaken similar work on bioenergy futures as a consultancy for the Biotechnology and Biological Sciences Research Council (BBSRC) [48]. While this did not incorporate the discrete choice element, which offers a more robust way to incorporate human actors into scenarios, the SQF approach was used to develop a set of descriptions of possible futures. These were then used to create a toolkit of resources for public dialogues, where participants were invited to use the materials to explore the implications of the scenarios, particularly by varying the components and inserting different actors [49]. While the independent evaluation noted various practical lessons for future exercises, it found a high degree of enthusiasm and endorsement among participants [50]. This work was not fully connected to the policy process - many critical decisions had been made in advance of the dialogue events - but the evaluation identified the method's potential as a source of stakeholder input based on active involvement with, and learning about, emerging issues. A particular feature of the bioenergy work was the participants' sense that the outcomes of their discussions were not predetermined by the scenario tools that they were given, allowing the policy community to hear voices and arguments that would not otherwise have been available to them. By retaining the qualitative elements, and developing narratives that have some of the features of science fiction prototyping, while respecting constraints of plausibility, the future visions remained accessible and transparent to non-specialist audiences. It would be useful to test this against the quantitative XLRM approach which, we suspect, may carry more legitimacy with some classes of experts, while mystifying other important stakeholders. A participative process does not, of course, guarantee universal popular consent. However, there is good evidence that a sense of having been listened to contributes to accepting adverse decisions as legitimate [51].

The travails of the HS2 project, to construct a high-speed rail line along the corridor studied by FUTURENET, or the debate about an additional runway at one of the airports serving London, are reminders of the tensions that emerge from a planning process that pays little heed to contemporary interest in ideals such as participatory decision making, and transparency. Our approach does not necessarily make decision-making by infrastructure planners easier or simpler. However, it does ensure that they consider a wider range of relevant variables when making their decisions about the future. These variables, both qualitative and quantitative, capture as much as possible about the context in which travel decisions are taken - both on the supply (in our case infrastructure and transport service characteristics) and demand (travellers' requirements for mobility) side. For the former especially, quantitative choice models can be effectively enhanced by the use of extended social, behavioural and psychological information about consumers, able to better profile the context of their consumption decisions. Where these are conventionally treated as individual unit acts, we have established that these are embedded in complex social networks and cultural expectations about mobility. By considering long-term investments within this framework, planners can explore the relevance of their decisions to a variety of possible futures, rather than simply projecting existing lines on a graph, and consider how to design 
for adaptation and resilience from the outset rather than finding that expensive mistakes have been made, which either waste resources or lead to costly retrofits. In facilitating the engagement of a wider group of stakeholders, this approach may also offer the opportunity to avoid the paralysis that is often thought to characterize decision-making about major infrastructure projects where policy elites find their decisions frustrated by various forms of, legal or extra-legal, popular resistance. Collaborative approaches to decision-making may seem more costly up front but save a great deal of subsequent delay and expense.

\section{Acknowledgements}

The authors would like to acknowledge the UK based Engineering and Physical Sciences Research Council (EPSRC) for funding the 'FUTURENET' (Future Resilient Transport Networks) project. This paper reports work conducted under grants EP/G060495/1 and EP/G060770/1. The authors would like to thank the FUTURENET workshops participants and project partners for some useful discussions, and also acknowledge the market research company Ipsos MORI that conducted the data collection. Murray Goulden also acknowledges the EPSRC Horizon Digital Economy Research Hub grant (EP/G065802/1) 


\section{Reference list}

[1] R. Van Nes, S. Hoogendoorn-Lanser, F.S. Koppelman, Using choice sets for estimation and prediction in route choice, Transportmetrica, 4 (2008) 83-96.

[2] S. Amstrong, Findings from evidence-based forecasting: methods for reducing forecast error, International Journal of Forecasting, 22 (2006) 583-598.

[3] R. Garrido, H.S. Mahmassani, Forecasting freight transportation demand with the spacetime multinomial probit model, Transportation Research Part B: Methodological, 34 (2000) 403-418.

[4] R. Hickman, D. Banister, Looking over the horizon: Transport and reduced CO2 emissions in the UK by 2030, Transport Policy, 14 (2007) 377-387.

[5] D. Stead, D. Banister, Transport policy scenario-building, Transportation Planning and Technology, 26 (2003) 513-536.

[6] R. Hickman, S. Saxena, D. Banister, O. Ashiru, Examining transport futures with scenario analysis and MCA, Transportation Research Part A: Policy and Practice, 46 (2012) 560-575. [7] A.M. Zanni, A.L. Bristow, Emissions of CO2 from road freight transport in London: Trends and policies for long run reductions, Energy Policy, 38 (2010) 1774-1786.

[8] M. Tran, D. Banister, J.D.K. Bishop, M.D. McCulloch, Simulating early adoption of alternative fuel vehicles for sustainability, Technological Forecasting and Social Change, 80 (2013) 865-875.

[9] G. Lyons, P. Goodwin, Grow, peak or plateau - the outlook for car travel, in, Discussion paper. New Zealand Ministry of Transport - http://eprints.uwe.ac.uk/23277/, 2014.

[10] S. Inayatullah, Alternative futures of transport, Foresight, 5 (2003) 34-43.

[11] J. Wangel, S. Gustafsson, O. Svane, Goal-based socio-technical scenarios: greening the mobility practices in the Stockholm City district of Bromma, Sweden, Futures, 47 (2013) 7992.

[12] P. Moriarty, D. Honnery, Low-mobility:the futures of transport, Futures, 40 (2008) 865872.

[13] S. Potter, M. Skinner, On transport integration: a contribution to better understanding, Futures, 32 (2000) 275-287.

[14] C. Hubbers, G. Lyons, Assessing future travel demand: a need to account for nontransport technologies?, Foresight, 15 (2013) 211-227.

[15] M.B. Charles, H. To, P. Gillet, T. von der Heidt, R. Kivits, Transport energy futures: exploring the geopolitical dimension, Futures, 43 (2011) 1142-1153.

[16] A. Suominen, A. Tuominen, J. Kantola, Analyzing prospects of portable fuel cells with an expert opinion study, Futures, 43 (2011) 513-524.

[17] R. Kivits, M.B. Charles, N. Ryan, A post-carbon aviation future: airports and the transition to a cleaner aviation sector, Futures, 42 (2010) 199-211.

[18] R. Butler, Tourism in the furure: cylce, waves or wheels?, Futures, 41 (2009) 346-352.

[19] I. Yeoman, C. Greenwood, U. Mc-Mahon-Beattie, The future of Scotland international tourism market, Futures, 41 (2009) 387-395.

[20] C.S.A. van Koppen, A.P.J. Mol, J.P.M. van Tatenhove, Coping with extreme climate events: institutional flocking, Futures, 42 (2010) 749-758.

[21] M. Goulden, R. Dingwall, Chapter 2 Managing the Future: Models, Scenarios and the Control of Uncertainty, in: Transport and Climate Change, 2012, pp. 9-37.

[22] J. Bleecker, Design fiction: a short essay on design, science, fact and fiction, in, Near Future Laboratory - http://blog.nearfuturelaboratory.com/2009/03/17/design-fiction-a-shortessay-on-design-science-fact-and-fiction/, 2009.

[23] E. Morris, From horse power to horsepower, Access, 30 (2007) 2-9.

[24] A.V. Cicourel, Method and measurement in Sociology, Free Press, New York, 1964. 
[25] D.G. Groves, R.J. Lempert, A new analytic method for finding policy-relevant scenarios, Global Environmental Change, 17 (2007) 73-85.

[26] R.J. Lempert, D.G. Groves, S.W. Popper, S.C. Bankes, A General, Analytic Method for Generating Robust Strategies and Narrative Scenarios, Management Science, 52 (2006) 514528.

[27] H. Kahn, A.J. Wiener, The Year 2000: A Framework for Speculation on the Next Thirtythree Years, Macmillan, 1967.

[28] H.A. Linstone, M. Turoff, The Delphi Method: Techniques and Applications, AddisonWesley Educational Publisher Inc, Reading, Mass., 1975.

[29] B.D. Johnson, Science Fiction Prototyping: Designing the Future with Science Fiction, Morgan \& Claypool, San Rafael, Calif., 2011.

[30] J. Urry, Mobilities, Polity Press, Cambridge, 2007.

[31] ONS, 2011 UK Censuses, in, Office for National Statistics - Available at:

http://www.ons.gov.uk/ons/guide-method/census/2011/uk-census/index.html, 2013.

[32] DCLG, Household Projections, 2008 to 2033, England. Housing Statistical Release, in,

Department of Communities and Local Government, London, 2010.

[33] B. Devall, The Deep Ecology Movement, Natural Resources Journal, 20 (1980) 299-

332.

[34] R.L. Sandor, E.C. Bettelheim, I.R. Swingland, An overview of a free-market approach to climate change and conservation, Philosophical Transactions of the Royal Society of London. Series A: Mathematical, Physical and Engineering Sciences, 360.1797 (2002) 1607-1620.

[35] J. Louviere, Conjoint analysis of stated preferences: a review of theory, methods, recent developments and external validity, Journal of Transport Economics and Policy, 22 (1988)

93-119.

[36] T. Elrod, J. Louviere, K.S. Davey, An empirical comparison of rating-based and choicebased conjoint moldels, Journal of Marketing Research, 29 (1992) 368-377.

[37] J. Louviere, D.A. Hensher, On the design and analysis of simulated choice or allocation experiment in travel choice modelling, Transportation Research Record: Journal of the Transportation Research Board, 890 (1982) 11-17.

[38] N. Hanley, S. Mourato, R.E. Wright, Choice modelling approaches: a superior alternative for environmental evaluation?, Journal of Economic Surveys, 15 (2001) 435-462. [39] M. Ryan, D.A. Scott, C. Donaldson, Valuing health care using willingness to pay: a comparison of the payment card and dichotomous choice methods, Journal of Health Economics, 23 (2004) 237-258.

[40] J. Louviere, Experimental choice analysis: introduction and overview, Journal of Business Research, 23 (1991) 291-297.

[41] K.J. Lancaster, A new approach to consumer theory, The Journal of Political Economy, 74 (1966) 132-157.

[42] M. Morrison, J. Bennet, R. Blamey, J. Louviere, Choice modelling and tests of benefit transfer, American Journal of Agricultural Economics, 84 (2002) 161-170.

[43] D. McFadden, Economic choices, The American Economic Review, 91 (2001) 351-378. [44] D.A. Hensher, Stated preference analysis of travel choice: the state of practice, Transportation, 21 (1994) 107-133.

[45] Z. Li, D.A. Hensher, J.M. Rose, Willingness to pay for travel time reliability in passenger transport: A review and some new empirical evidence, Transportation Research Part E: Logistics and Transportation Review, 46 (2010) 384-403.

[46] M.C.J. Bliemer, J.M. Rose, Experimental design influences on stated choice outputs: An empirical study in air travel choice, Transportation Research Part A: Policy and Practice, 45 (2011) 63-79. 
[47] T.J. Ryley, A.M. Zanni, An examination of the relationship between social interactions and travel uncertainty, Journal of Transport Geography, 31 (2013) 249-257.

[48] R. Dingwall, A. Balmer, M. Goulden, BBSRC Sustainable Bioenergy Scenario Tool, in, Biotechnology and Biological Science Research Council (BBSRC) -

http://www.bbsrc.ac.uk/publications/topic/sustainable-bioenergy-scenario-tool.aspx 2012.

[49] BBSRC, Dialogue materials, in, Biotechnology and Biological Science Research

Council - http://www.bbsrc.ac.uk/engagement/dialogue/activities/bioenergy-

dialogue/dialogue-materials/, 2012.

[50] Collingwood Environmental Planning Limited, Evaluation of BBSRC's Bioenergy Public Dialogue, in, Prepared for the Biotechnology and Biological Sciences Research Council and Sciencewise, 2014.

[51] T.R. Tyler, Why people obey the law, Princeton University Press, New Jersey, USA, 2006. 


\section{Appendix}

Table A1. Attributes and levels used to create the choice cards

\begin{tabular}{|c|c|c|c|c|}
\hline Method of travel & Air & Train & Car & Coach \\
\hline \multirow[t]{4}{*}{ 1. Scheduled departure time } & $\begin{array}{l}\text { Morning } \\
\text { (between } \\
6.00-12.00 \text { ) }\end{array}$ & $\begin{array}{l}\text { Morning } \\
\text { (between } \\
6.00-12.00)\end{array}$ & & $\begin{array}{l}\text { Morning } \\
\text { (between } \\
6.00-12.00 \text { ) }\end{array}$ \\
\hline & $\begin{array}{l}\text { Afternoon } \\
\text { (between } \\
12.00- \\
17.00 \text { ) }\end{array}$ & $\begin{array}{l}\text { Afternoon } \\
\text { (between } \\
12.00- \\
17.00 \text { ) }\end{array}$ & & $\begin{array}{l}\text { Afternoon } \\
\text { (between } \\
12.00- \\
17.00 \text { ) }\end{array}$ \\
\hline & $\begin{array}{l}\text { Evening } \\
\text { (between } \\
17.00- \\
21.00 \text { ) }\end{array}$ & $\begin{array}{l}\text { Evening } \\
\text { (between } \\
17.00- \\
21.00 \text { ) }\end{array}$ & & $\begin{array}{l}\text { Evening } \\
\text { (between } \\
17.00- \\
21.00 \text { ) }\end{array}$ \\
\hline & $\begin{array}{l}\text { Night (after } \\
\text { 21.00) }\end{array}$ & $\begin{array}{l}\text { Night (after } \\
\text { 21.00) }\end{array}$ & & $\begin{array}{l}\text { Night (after } \\
21.00 \text { ) }\end{array}$ \\
\hline \multirow{5}{*}{$\begin{array}{l}\text { 2. Time taken to reach } \\
\text { airport, railway or coach } \\
\text { station + waiting time } \\
\text { (check-in, security, etc.) }\end{array}$} & $\begin{array}{l}1 \text { hour and } \\
30 \text { minutes }\end{array}$ & 30 minutes & & 30 minutes \\
\hline & 2 hours & 45 minutes & & 45 minutes \\
\hline & $\begin{array}{l}2 \text { hours and } \\
30 \text { minutes }\end{array}$ & 1 hour & & 1 hour \\
\hline & 3 hours & $\begin{array}{l}1 \text { hour and } \\
15 \text { minutes }\end{array}$ & & $\begin{array}{l}1 \text { hour and } \\
15 \text { minutes }\end{array}$ \\
\hline & $\begin{array}{l}3 \text { hours and } \\
30 \text { minutes }\end{array}$ & $\begin{array}{l}1 \text { hour and } \\
30 \text { minutes }\end{array}$ & & $\begin{array}{l}1 \text { hour and } \\
30 \text { minutes }\end{array}$ \\
\hline \multirow{4}{*}{$\begin{array}{l}\text { 3. Time taken for the } \\
\text { journey in normal } \\
\text { conditions (including } \\
\text { necessary breaks) }\end{array}$} & $\begin{array}{l}1 \text { hour and } \\
10 \text { minutes }\end{array}$ & $\begin{array}{l}3 \text { hours and } \\
30 \text { minutes }\end{array}$ & $\begin{array}{l}6 \text { hours and } \\
30 \text { minutes }\end{array}$ & 8 hours \\
\hline & $\begin{array}{l}1 \text { hour and } \\
30 \text { minutes }\end{array}$ & 4 hours & 7 hours & $\begin{array}{l}8 \text { hours and } \\
30 \text { minutes }\end{array}$ \\
\hline & $\begin{array}{l}1 \text { hour and } \\
45 \text { minutes }\end{array}$ & $\begin{array}{l}4 \text { hours and } \\
30 \text { minutes }\end{array}$ & $\begin{array}{l}7 \text { hours and } \\
30 \text { minutes }\end{array}$ & 9 hours \\
\hline & & 5 hours & 8 hours & $\begin{array}{l}9 \text { hours and } \\
30 \text { minutes }\end{array}$ \\
\hline \multirow{7}{*}{$\begin{array}{l}\text { charges), and other costs } \\
\text { to reach your final } \\
\text { destination for }\end{array}$} & $£ 50.00$ & $£ 40.00$ & $£ 60.00$ & $£ 20.00$ \\
\hline & $£ 80.00$ & $£ 70.00$ & $£ 90.00$ & $£ 40.00$ \\
\hline & $£ 110.00$ & $£ 100.00$ & $£ 120.00$ & $£ 60.00$ \\
\hline & $£ 140.00$ & $£ 130.00$ & $£ 150.00$ & $£ 80.00$ \\
\hline & $£ 170.00$ & $£ 160.00$ & $£ 180.00$ & $£ 100.00$ \\
\hline & $£ 200.00$ & $£ 190.00$ & $£ 210.00$ & \\
\hline & $£ 230.00$ & $£ 220.00$ & $£ 240.00$ & \\
\hline \multirow[t]{3}{*}{ 5. Early by: } & 10 minutes & 10 minutes & 20 minutes & 10 minutes \\
\hline & 20 minutes & 20 minutes & 40 minutes & 20 minutes \\
\hline & 30 minutes & 30 minutes & 1 hour & 30 minutes \\
\hline \multirow{3}{*}{$\begin{array}{l}\text { 6. Probability of early } \\
\text { arrival }\end{array}$} & $0 \%$ & $0 \%$ & $0 \%$ & $0 \%$ \\
\hline & $10 \%$ & $10 \%$ & $10 \%$ & $10 \%$ \\
\hline & $20 \%$ & $20 \%$ & $20 \%$ & $20 \%$ \\
\hline
\end{tabular}




\begin{tabular}{|c|c|c|c|c|}
\hline \multirow[t]{6}{*}{ 7. Magnitude of Delay 1} & 15 minutes & 15 minutes & 15 minutes & 15 minutes \\
\hline & 45 minutes & 45 minutes & 45 minutes & 45 minutes \\
\hline & $\begin{array}{l}1 \text { hour and } \\
30 \text { minutes }\end{array}$ & $\begin{array}{l}1 \text { hour and } \\
30 \text { minutes }\end{array}$ & $\begin{array}{l}1 \text { hour and } \\
30 \text { minutes }\end{array}$ & $\begin{array}{l}1 \text { hour and } \\
30 \text { minutes }\end{array}$ \\
\hline & $\begin{array}{l}2 \text { hours and } \\
30 \text { minutes }\end{array}$ & $\begin{array}{l}2 \text { hours and } \\
30 \text { minutes }\end{array}$ & $\begin{array}{l}2 \text { hours and } \\
30 \text { minutes }\end{array}$ & $\begin{array}{l}2 \text { hours and } \\
30 \text { minutes }\end{array}$ \\
\hline & $\begin{array}{l}3 \text { hours and } \\
30 \text { minutes }\end{array}$ & $\begin{array}{l}3 \text { hours and } \\
30 \text { minutes }\end{array}$ & $\begin{array}{l}3 \text { hours and } \\
30 \text { minutes }\end{array}$ & $\begin{array}{l}3 \text { hours and } \\
30 \text { minutes }\end{array}$ \\
\hline & $\begin{array}{l}4 \text { hours and } \\
30 \text { minutes }\end{array}$ & $\begin{array}{l}4 \text { hours and } \\
30 \text { minutes }\end{array}$ & $\begin{array}{l}4 \text { hours and } \\
30 \text { minutes }\end{array}$ & $\begin{array}{l}4 \text { hours and } \\
30 \text { minutes }\end{array}$ \\
\hline \multirow[t]{3}{*}{ 8. Probability of delay 1} & $30 \%$ & $30 \%$ & $30 \%$ & $30 \%$ \\
\hline & $40 \%$ & $40 \%$ & $40 \%$ & $40 \%$ \\
\hline & $50 \%$ & $50 \%$ & $50 \%$ & $50 \%$ \\
\hline \multirow[t]{6}{*}{ 9. Magnitude of delay 2} & 30 minutes & 30 minutes & 30 minutes & 30 minutes \\
\hline & 1 hour & 1 hour & 1 hour & 1 hour \\
\hline & 2 hours & 2 hours & 2 hours & 2 hours \\
\hline & 3 hours & 3 hours & 3 hours & 3 hours \\
\hline & 4 hours & 4 hours & 4 hours & 4 hours \\
\hline & 5 hours & 5 hours & 5 hours & 5 hours \\
\hline \multirow[t]{3}{*}{ 10. Probability of delay 2} & $40 \%$ & $40 \%$ & $40 \%$ & $40 \%$ \\
\hline & $50 \%$ & $50 \%$ & $50 \%$ & $50 \%$ \\
\hline & $60 \%$ & $60 \%$ & $60 \%$ & $60 \%$ \\
\hline \multirow{5}{*}{$\begin{array}{l}\text { 11. Time to reach your } \\
\text { destination once arrived } \\
\text { (this includes additional } \\
\text { waiting time for } \\
\text { disembarkment) }\end{array}$} & 1 hour & 20 minutes & & 20 minutes \\
\hline & $\begin{array}{l}1 \text { hour and } \\
30 \text { minutes }\end{array}$ & 40 minutes & & 40 minutes \\
\hline & 2 hours & 1 hour & & 1 hour \\
\hline & $\begin{array}{l}2 \text { hours and } \\
30 \text { minutes }\end{array}$ & $\begin{array}{l}1 \text { hour and } \\
20 \text { minutes }\end{array}$ & & $\begin{array}{l}1 \text { hour and } \\
20 \text { minutes }\end{array}$ \\
\hline & 3 hours & $\begin{array}{l}1 \text { hour and } \\
40 \text { minutes }\end{array}$ & & $\begin{array}{l}1 \text { hour and } \\
40 \text { minutes }\end{array}$ \\
\hline
\end{tabular}


Table A2. Definition of variables used in the analysis

\begin{tabular}{|c|c|}
\hline Variable & Definition \\
\hline AIR & Alternative specific constant for Air option (base: no travel) \\
\hline TRAIN & Alternative specific constant for Train option (base: no travel) \\
\hline CAR & Alternative specific constant for Car option (base: no travel) \\
\hline $\mathrm{COACH}$ & Alternative specific constant for Coach option (base: no travel) \\
\hline \multicolumn{2}{|c|}{ All the following variables where inserted in the utility function as alternative specific } \\
\hline _DEPMO & Morning departure (base Night departure) for Air, Train and Coach \\
\hline DEPAF & Afternoon departure (base Night departure) for Air, Train and Coach \\
\hline _DEPEV & Evening Departure (base Night departure) for Air, Train and Coach \\
\hline ACCTIM & Time taken to reach transport terminal for Air, Train and Coach \\
\hline DURAT & Duration of the trip for Air, Train, Car and Coach \\
\hline COST & Cost, for Air, Train, Car and Coach \\
\hline EGT & Time to reach your final destination once arrived, for Air, Train and Coach \\
\hline ESDE & Expected value of schedule early, for Air, Train, Car and Coach \\
\hline ESDL & Expected value of schedule delay, for Air, Train, Car and Coach \\
\hline -GALES & Severe Weather Alert: Severe gales, for Air, Train, Car and Coach \\
\hline -RAIN & Severe Weather Alert: Heavy rain, for Air, Train, Car and Coach \\
\hline _SNOW & Severe Weather Alert: Heavy snow and icy roads, for Air, Train, Car and Coach \\
\hline _THUND & Severe Weather Alert: Thunderstorm and lighting, for Air, Train, Car and Coach \\
\hline _HOT & Severe Weather Alert: Heat and sun for Air, Train, Car and Coach \\
\hline FOG & Severe Weather Alert: Dense fog, for Air, Train, Car and Coach \\
\hline _LEIS & Reason for the trip: leisure, for Air, Train, Car and Coach \\
\hline FRREL & Reason for the trip: visiting friends and relatives, for Air, Train, Car and Coach \\
\hline -WADU & Trip with adults only, for Air, Train, Car and Coach \\
\hline _WCHLD & Trip with children, for Air, Train, Car and Coach \\
\hline _IMPORT & Importance of the trip, for Air, Train, Car and Coach \\
\hline
\end{tabular}


Table A3. Results of the Multinomial Logit estimations

\begin{tabular}{|c|c|c|c|c|c|c|c|c|c|c|c|c|c|c|}
\hline \multirow{2}{*}{ Variable } & \multicolumn{2}{|c|}{ Group 1 - London } & \multicolumn{2}{|c|}{ Group 6 - London } & \multicolumn{2}{|c|}{ London total } & \multicolumn{2}{|c|}{ Group 5 - Glasgow } & \multicolumn{2}{|c|}{ Group 8 - Glasgow } & \multicolumn{2}{|c|}{ Glasgow total } & \multicolumn{2}{|c|}{ Total sample } \\
\hline & Coeff. & T-stat & Coeff. & T-stat & Coeff. & T-stat & Coeff. & T-stat & Coeff. & T-stat & Coeff. & T-stat & Coeff. & T-stat \\
\hline AIR & 0.638 & 0.43 & 0.974 & 0.80 & 1.992 & $* * * 5.60$ & 3.090 & $* * * 3.47$ & 2.994 & $* 1.71$ & 2.183 & $* * * 6.00$ & 2.070 & $* * * 8.17$ \\
\hline AIRDEPMO & -0.408 & -1.26 & 0.289 & 1.12 & -0.149 & -1.92 & 0.043 & 0.23 & -0.154 & -0.42 & 0.019 & 0.24 & -0.066 & -1.21 \\
\hline AIRDEPAF & -0.165 & -0.45 & 0.271 & 0.92 & 0.097 & 1.11 & -0.347 & -1.59 & -0.634 & -1.46 & -0.081 & -0.92 & 0.010 & 0.16 \\
\hline AIRDEPEV & 0.216 & 0.56 & 0.049 & 0.15 & 0.063 & 0.68 & -0.276 & -1.21 & -0.082 & -0.18 & -0.043 & -0.45 & 0.009 & 0.14 \\
\hline AIRACCTI & 0.003 & 0.94 & -0.002 & -0.68 & -0.001 & -0.69 & -0.002 & -1.25 & 0.001 & 0.18 & -0.001 & -0.92 & -0.001 & -1.15 \\
\hline AIRDURAT & 0.009 & 1.02 & 0.007 & 0.97 & 0.002 & 0.98 & 0.002 & 0.42 & 0.008 & 0.8 & 0.002 & 0.89 & 0.002 & 1.32 \\
\hline AIRCOST & -0.004 & $*-1.74$ & -0.007 & $* * *-3.75$ & -0.006 & $* * *-11.85$ & -0.006 & $* * *-4.67$ & -.0008 & ***-3.37 & -0.007 & $* * *-13.54$ & -0.006 & $* * *-17.84$ \\
\hline AIREGT & 0.003 & 1.03 & 0.000 & -0.1 & -0.002 & $* * *-3.22$ & -0.002 & -1.15 & -0.003 & -0.97 & -0.002 & $* *-2.36$ & -0.002 & $* * *-3.96$ \\
\hline AIRESDE & 0.065 & 0.95 & 0.037 & 0.69 & 0.027 & 1.64 & 0.003 & 0.06 & 0.036 & 0.45 & .043 & $* * * 2.59$ & 0.033 & $* * * 2.88$ \\
\hline AIRESDL & -0.003 & -1.19 & -0.002 & -0.91 & -0.002 & $* * *-3.37$ & -0.002 & -1.27 & -0.001 & -0.39 & -0.002 & $* * *-3.80$ & -0.002 & $* * *-5.09$ \\
\hline AGALES & -1.676 & $* * *-2.85$ & -1.471 & $* * *-3.52$ & -1.345 & $* * *-11.00$ & -1.882 & $* * *-5.73$ & -2.450 & $* * *-3.55$ & -1.482 & $* * *-11.26$ & -1.414 & $* * *-15.84$ \\
\hline ARAIN & -0.634 & -1.11 & -0.710 & $*_{-1.83}$ & -0.693 & $* * *-5.43$ & -0.455 & -1.14 & -0.334 & -0.38 & -0.191 & -1.25 & -0.485 & $* * *-5.03$ \\
\hline ASNOW & -2.522 & $* * *-5.03$ & -1.232 & $* * *-3.34$ & -1.564 & $* * *-13.81$ & -2.184 & $* * *-7.14$ & -2.409 & $* * *-3.78$ & -1.830 & $* * *-15.36$ & $\begin{array}{l}-1.688 \\
\end{array}$ & $* * *-20.63$ \\
\hline ATHUND & -2.309 & $* * *-4.08$ & -0.981 & $* *-2.49$ & -1.034 & $* * *-8.21$ & -1.688 & $* * *-4.76$ & -2.044 & $* * *-2.67$ & -1.223 & $* * *-9.060$ & -1.125 & $* * *-12.25$ \\
\hline
\end{tabular}




\begin{tabular}{|c|c|c|c|c|c|c|c|c|c|c|c|c|c|c|}
\hline AHOT & -0.332 & -0.56 & -0.126 & -0.29 & -0.091 & -0.66 & 0.121 & 0.28 & -1.303 & $*-1.74$ & 0.106 & 0.68 & 0.006 & 0.06 \\
\hline AFOG & -2.015 & $* * *-3.54$ & -1.379 & $* * *-3.36$ & -1.271 & $* * *-10.01$ & -2.033 & $* * *-5.91$ & -2.582 & $* * *-3.53$ & -1.357 & $* * *-10.03$ & -1.308 & $* * *-14.2$ \\
\hline ALEIS & 0.122 & 0.29 & 0.285 & 0.95 & -0.003 & -0.03 & -0.184 & -0.77 & 0.318 & 0.61 & 0.001 & 0.01 & 0.039 & 0.61 \\
\hline AFRREL & -0.280 & -0.71 & -0.327 & -1.13 & -0.140 & -1.54 & -0.428 & $*_{-1.66}$ & -0.468 & -0.95 & -0.287 & $* * *-2.82$ & -0.196 & $* * *-2.9$ \\
\hline AWADU & 0.321 & 0.73 & 0.420 & 1.18 & 0.098 & 0.93 & 0.484 & $* * 2.02$ & 0.870 & $* 1.65$ & 0.381 & $* * * 3.90$ & 0.301 & $* * * 4.26$ \\
\hline AWCHLD & -1.297 & $* * *-3.09$ & -0.169 & -0.46 & -0.254 & $* *-2.49$ & 0.394 & 1.44 & 0.251 & 0.38 & 0.300 & $* * * 2.92$ & 0.073 & 1.02 \\
\hline AIMPORT & 0.113 & $* * 2.09$ & 0.109 & $* * * 2.76$ & 0.096 & ***7.73 & 0.091 & $* * * 2.76$ & 0.038 & 0.55 & 0.138 & $* * * 10.14$ & 0.113 & $* * * 12.45$ \\
\hline TRAIN & 3.571 & $* * * 3.14$ & 2.565 & $* * * 2.86$ & 2.941 & $* * * 10.97$ & 3.562 & $* * * 4.9$ & 3.716 & $* * * 2.77$ & 2.702 & $* * * 9.44$ & 2.826 & $* * * 14.48$ \\
\hline TRDEPMOR & 0.501 & 1.61 & 0.112 & 0.41 & 0.233 & $* * * 2.87$ & 0.161 & 0.76 & 0.450 & 1.15 & 0.202 & $* * 2.37$ & 0.214 & ***3.66 \\
\hline TRDEPAFT & -0.318 & -1.05 & 0.046 & 0.18 & 0.088 & 1.16 & -0.060 & -0.30 & 0.300 & 0.83 & -0.023 & -0.29 & 0.031 & 0.56 \\
\hline TRDEPEVE & 0.205 & 0.67 & -0.154 & -0.61 & 0.138 & $* 1.83$ & -0.057 & -0.29 & 0.304 & 0.84 & 0.102 & 1.30 & 0.121 & $* * 2.24$ \\
\hline TRACCTIM & -0.005 & -0.88 & 0.004 & 0.92 & -0.001 & -0.54 & -0.001 & -0.41 & -0.001 & -0.14 & -0.003 & $*-1.90$ & -0.002 & $*-1.68$ \\
\hline TRDURAT & -0.005 & -1.4 & -0.004 & -1.39 & -0.004 & $* * *-5.11$ & -0.005 & $* *-2.35$ & -0.005 & -1.11 & -0.004 & $* * *-4.09$ & -0.004 & $* * *-6.47$ \\
\hline TRCOST & -0.006 & $* * *-3.07$ & -0.006 & $* * *-3.80$ & -0.006 & $* * *-13.26$ & -0.006 & $* * *-5.15$ & -0.006 & $* * *-2.92$ & -0.007 & $* * *-13.75$ & -0.006 & $* * *-19.1$ \\
\hline TREGT & 0.002 & 0.41 & 0.000 & -0.08 & -0.002 & $* *-2.29$ & -0.001 & -0.61 & -0.002 & -0.49 & -0.002 & $* *-2.07$ & -0.002 & $* * *-2.98$ \\
\hline TRESDE & 0.008 & 0.11 & -0.095 & -1.51 & -0.045 & $* *-2.44$ & -0.066 & -1.35 & -0.083 & -0.91 & -0.055 & $* * *-2.79$ & -0.051 & $* * *-3.75$ \\
\hline TRESDL & -0.001 & -0.28 & -0.002 & -1.07 & -0.001 & -1.31 & -0.001 & -0.96 & 0.001 & 0.39 & -0.001 & -1.59 & -0.001 & $* *-2.12$ \\
\hline
\end{tabular}




\begin{tabular}{|c|c|c|c|c|c|c|c|c|c|c|c|c|c|c|}
\hline TGALES & -0.330 & -0.62 & -0.896 & $* *-2.39$ & -0.770 & $* * *-6.75$ & -1.191 & $* * *-3.69$ & -1.410 & $* *-2.20$ & -0.650 & $* * *-5.18$ & -0.711 & $* * *-8.46$ \\
\hline RAINT & -0.104 & -0.18 & -0.753 & $*-1.94$ & -0.300 & $* *-2.43$ & -0.274 & -0.67 & -0.164 & -0.18 & 0.136 & 0.89 & -0.130 & -1.36 \\
\hline TSNOW & -1.666 & $* * *-3.63$ & -1.140 & $* * *-3.02$ & -1.355 & $* * *-12.26$ & -2.002 & $* * *-6.29$ & -2.094 & $* * *-3.33$ & -1.489 & $* * *-12.40$ & -1.411 & $* * *-17.38$ \\
\hline TTHUND & -0.584 & -1.22 & -0.768 & $* *-2.06$ & -0.467 & $* * *-3.94$ & -0.745 & $* *-2.18$ & -0.524 & -0.76 & -0.461 & $* * *-3.55$ & -0.462 & $* * *-5.28$ \\
\hline THOT & -0.360 & -0.59 & -0.341 & -0.77 & -0.098 & -0.71 & -0.024 & -0.05 & -1.021 & -1.37 & -0.003 & $\begin{array}{l}-0.02 \\
\end{array}$ & -0.056 & -0.53 \\
\hline TFOG & -0.460 & -0.93 & -0.586 & -1.63 & -0.391 & $* * *-3.42$ & -0.688 & $* *-2.14$ & -1.205 & $*-1.85$ & -0.350 & $* * *-2.75$ & -0.374 & $* * *-4.41$ \\
\hline TLEIS & 0.093 & 0.24 & 0.085 & 0.29 & 0.028 & 0.33 & 0.246 & 1.04 & 0.186 & 0.37 & 0.056 & 0.62 & 0.059 & 0.94 \\
\hline TFRREL & -0.530 & -1.43 & -0.614 & $* *-2.18$ & -0.115 & -1.33 & 0.030 & 0.12 & -0.566 & -1.24 & -0.154 & -1.56 & -0.120 & $*_{-1.84}$ \\
\hline TWADU & -0.413 & -0.95 & 0.366 & 1.06 & 0.024 & 0.24 & 0.218 & 0.91 & 0.874 & *1.71 & 0.444 & $* * * 4.62$ & 0.256 & $* * * 3.71$ \\
\hline TWCHLD & -1.283 & $* * *-3.41$ & 0.052 & 0.15 & -0.249 & $* *-2.57$ & 0.424 & 1.59 & 1.182 & $* 1.95$ & 0.389 & $* * * 3.86$ & 0.081 & 1.17 \\
\hline TIMPORT & 0.085 & *1.72 & 0.083 & $* * 2.21$ & 0.080 & $* * * 6.81$ & 0.079 & $* * 2.40$ & 0.036 & 0.56 & 0.125 & $* * * 9.35$ & 0.099 & $* * * 11.21$ \\
\hline CAR & 2.352 & 1.21 & 2.817 & *1.81 & 0.878 & *1.75 & 2.145 & 1.42 & -0.631 & -0.21 & 1.174 & $* * 2.03$ & 1.029 & 2.73 \\
\hline CARDURAT & -0.002 & -0.49 & -0.004 & -1.35 & -0.001 & -0.49 & -0.003 & -1.03 & 0.004 & 0.62 & -0.001 & -0.76 & -0.001 & -0.94 \\
\hline CARCOST & -0.002 & -0.93 & -0.003 & $*-1.70$ & -0.003 & $* * *-5.53$ & -0.004 & $* *-2.11$ & -0.008 & $* *-2.11$ & -0.006 & $* * *-8.10$ & -0.005 & $* * *-9.47$ \\
\hline CARESDE & -0.027 & -0.48 & 0.071 & *1.75 & 0.009 & 0.69 & 0.054 & 1.42 & 0.055 & 0.77 & -0.006 & -0.40 & 0.004 & 0.35 \\
\hline CARESDL & -0.005 & $*-1.90$ & -0.004 & $* *-2.07$ & -0.001 & $* *-2.02$ & 0.000 & 0.05 & 0.000 & 0.11 & -0.003 & $* * *-3.13$ & -0.001 & $* * *-3.47$ \\
\hline CAGALES & -0.737 & -1.17 & -0.935 & $* *-2.18$ & -1.127 & $* * *-7.66$ & -1.789 & $* * *-3.88$ & -1.558 & $*-1.86$ & -1.041 & $* * *-6.13$ & -1.088 & $* * *-9.8$ \\
\hline
\end{tabular}




\begin{tabular}{|c|c|c|c|c|c|c|c|c|c|c|c|c|c|c|}
\hline CARAIN & -1.028 & -1.39 & -1.062 & $* *-2.27$ & -0.658 & $* * *-4.28$ & -0.317 & -0.66 & -0.130 & -0.13 & -0.286 & -1.48 & -0.516 & $* * *-4.31$ \\
\hline CASNOW & -2.419 & $* * *-3.67$ & -1.950 & $* * *-3.94$ & -2.109 & $* * *-12.39$ & -2.385 & $* * *-5.13$ & -102.17 & 0.00 & -2.009 & $* * *-10.93$ & -2.060 & $* * *-16.54$ \\
\hline CATHUND & -1.835 & $* * *-2.68$ & -1.616 & $* * *-3.16$ & -0.876 & $* * *-5.81$ & -1.062 & $* *-2.42$ & -1.209 & -1.39 & -0.675 & $* * *-4.04$ & -0.789 & $* * *-7.07$ \\
\hline CAHOT & 0.384 & 0.60 & -0.106 & -0.22 & 0.030 & 0.19 & 0.124 & 0.24 & -0.734 & -0.87 & -0.034 & -0.18 & 0.007 & 0.05 \\
\hline CAFOG & -2.426 & $* * *-2.82$ & -1.551 & $* * *-3.08$ & -1.286 & $* * *-7.96$ & -2.296 & $* * *-4.16$ & -101.57 & 0.00 & -1.508 & $* * *-7.49$ & -1.377 & $* * *-10.96$ \\
\hline CALEIS & 0.216 & 0.44 & 0.254 & 0.74 & 0.103 & 0.93 & 0.190 & 0.60 & 0.829 & 1.24 & -0.117 & -0.93 & -0.002 & -0.02 \\
\hline CAFRREL & -0.100 & -0.21 & -0.477 & -1.35 & 0.017 & 0.16 & -0.509 & -1.37 & 0.819 & 1.29 & 0.028 & 0.22 & 0.035 & 0.42 \\
\hline CAWADU & -0.165 & -0.30 & 0.690 & $* 1.74$ & 0.216 & *1.73 & 0.184 & 0.56 & 0.216 & 0.33 & 0.345 & $* * * 2.71$ & 0.241 & $* * * 2.74$ \\
\hline CAWCHLD & -1.302 & $* *-2.49$ & -0.226 & -0.51 & -0.574 & $* * *-4.16$ & 0.614 & *1.74 & -99.622 & 0.00 & 0.111 & 0.8 & -0.255 & $* * *-2.64$ \\
\hline CAIMPORT & 0.077 & 1.20 & 0.065 & 1.41 & 0.066 & $* * * 4.36$ & 0.030 & 0.66 & 0.088 & 0.96 & 0.100 & $* * * 5.58$ & 0.080 & $* * * 6.91$ \\
\hline$\overline{\mathrm{COACH}}$ & 5.290 & 1.35 & -0.070 & $\begin{array}{l}-0.02 \\
\end{array}$ & 2.938 & $* * * 3.27$ & 3.020 & 1.39 & 0.662 & 0.16 & -0.083 & $\begin{array}{l}-0.1 \\
\end{array}$ & 1.307 & $* * 2.14$ \\
\hline CODEPMOR & -0.036 & -0.05 & -0.394 & -0.80 & 0.196 & 1.32 & 0.280 & 0.81 & 0.524 & 0.74 & 0.229 & 1.62 & 0.221 & $* * 2.16$ \\
\hline CODEPAFT & -0.404 & -0.55 & -0.695 & -1.22 & 0.160 & 0.97 & 0.757 & $* * 2.02$ & -0.119 & -0.16 & 0.326 & $* * 2.12$ & 0.253 & $* * 2.25$ \\
\hline CODEPEVE & 0.180 & 0.27 & -0.373 & $\begin{array}{l}-0.73 \\
\end{array}$ & 0.111 & 0.72 & 0.427 & 1.23 & 0.151 & 0.21 & 0.119 & 0.84 & 0.124 & 1.19 \\
\hline COACCTIM & -0.011 & -0.90 & -0.016 & -1.5 & 0.000 & -0.10 & 0.018 & $* * * 2.95$ & -0.001 & -0.09 & 0.002 & 0.92 & 0.001 & 0.69 \\
\hline CODURAT & -0.008 & -1.03 & 0.003 & 0.53 & -0.005 & $* * *-2.96$ & -0.007 & $*-1.67$ & 0.00 & 0.00 & -0.00 & -0.06 & -0.002 & $* *-2.1$ \\
\hline COCOST & -0.007 & -0.95 & -0.012 & $*_{-1.93}$ & -0.009 & $* * *_{-} 4.89$ & -0.008 & $* *-2.11$ & 0.001 & 0.12 & -0.012 & $* * *-7.22$ & -0.010 & $* * *-8.58$ \\
\hline
\end{tabular}




\begin{tabular}{|c|c|c|c|c|c|c|c|c|c|c|c|c|c|c|}
\hline COEGT & 0.003 & 0.32 & -0.003 & -0.49 & -0.002 & -1.16 & 0.005 & 1.26 & 0.00 & 0.01 & 0.001 & 0.37 & -0.001 & -0.51 \\
\hline COESDE & -0.030 & -0.17 & -0.009 & -0.07 & -0.049 & -1.26 & -0.238 & $* *-2.44$ & -0.093 & -0.52 & -0.061 & -1.63 & -0.057 & $* *-2.14$ \\
\hline COESDL & -0.002 & -0.43 & 0.001 & 0.26 & -0.001 & -0.66 & 0.000 & 0.16 & -0.005 & -1.11 & -0.001 & -0.68 & -0.001 & -0.86 \\
\hline COGALES & -1.269 & -1.58 & -1.711 & $* *-2.49$ & -1.114 & $* * *-6.43$ & -1.755 & $* * *-4.11$ & -1.736 & $*-1.95$ & -0.920 & $* * *-5.53$ & -1.007 & $* * *-8.48$ \\
\hline CORAIN & -0.591 & -0.78 & -0.681 & -1.28 & -0.501 & $* * *-2.91$ & -0.506 & -1.06 & -0.352 & -0.33 & -0.054 & -0.29 & -0.324 & $* *-2.59$ \\
\hline COSNOW & -102.40 & 0.00 & -2.357 & $* * *-2.98$ & -1.589 & $* * *-9.06$ & -3.380 & $* * *-5.81$ & -1.613 & $* *-1.99$ & -1.870 & $* * *-10.37$ & -1.720 & $* * *-13.72$ \\
\hline COTHUND & -0.920 & -1.42 & -0.768 & -1.44 & -0.653 & $* * *-3.93$ & -0.927 & $* *-2.28$ & -0.746 & -0.85 & -0.590 & $* * *-3.54$ & -0.617 & $* * *-5.28$ \\
\hline $\mathrm{COHOT}$ & $\begin{array}{l}-1.193 \\
\end{array}$ & -1.27 & -0.320 & -0.53 & -0.365 & $*-1.90$ & -0.588 & -1.07 & -0.270 & -0.31 & -0.199 & -1.00 & -0.279 & $* *-2.04$ \\
\hline COFOG & -1.861 & $* *-2.10$ & $-1.007^{*}$ & $*-1.84$ & -0.931 & $* * *-5.39$ & -1.723 & $* * *-3.99$ & -1.746 & $*-1.75$ & -0.788 & $* * *-4.63$ & -0.848 & $* * *-7.05$ \\
\hline COLEIS & 0.341 & 0.60 & 0.269 & 0.61 & 0.102 & 0.82 & -0.024 & -0.08 & 0.579 & 0.87 & 0.312 & $* * * 2.66$ & 0.267 & $* * * 3.18$ \\
\hline COFRREL & -0.354 & -0.58 & 0.309 & 0.80 & -0.031 & -0.24 & -0.635 & $*-1.80$ & 0.465 & 0.78 & -0.316 & $* *-2.27$ & -0.159 & $*-1.69$ \\
\hline COWADU & 0.547 & 0.89 & 0.111 & 0.21 & -0.361 & $* *-2.18$ & -0.584 & $*-1.67$ & 0.289 & 0.43 & 0.020 & 0.15 & -0.094 & -0.92 \\
\hline COWCHLD & -0.489 & -0.84 & 0.123 & 0.25 & 0.026 & 0.19 & 0.369 & 1.1 & 0.546 & 0.7 & 0.579 & $* * * 4.57$ & 0.352 & $* * * 3.89$ \\
\hline COIMPORT & 0.030 & 0.38 & 0.026 & 0.46 & 0.058 & $* * * 3.31$ & 0.105 & $* * 2.44$ & 0.017 & 0.2 & 0.123 & $* * * 7.02$ & 0.087 & $* * * 7.08$ \\
\hline Obs. no. & & 536 & & 768 & & 8296 & & 1336 & & 408 & & 7920 & & 16216 \\
\hline Log-likel. & & -677.745 & & -1068.772 & & -11472.582 & & -1726.920 & & -474.936 & & -10498.261 & & -22089.898 \\
\hline Pseudo $R^{2}$ & & 0.073 & & 0.043 & & 0.050 & & 0.076 & & 0.100 & & 0.0681 & & 0.0574 \\
\hline
\end{tabular}

* = Significant at $90 \%$ level, $* *=95 \%$ level, *** = 99\% level 